\section{D) Check for updates}

Cite this: Dalton Trans., 2017, 46 10484

Received 17th May 2017,

Accepted 14th July 2017

DOI: 10.1039/c7dt01797a

rsc.li/dalton

\title{
DOTA analogues with a phosphinate- iminodiacetate pendant arm: modification of the complex formation rate with a strongly chelating pendant $\uparrow$
}

\author{
Soňa Procházková, Vojtěch Kubíček, (D) * Zuzana Böhmová, Kateřina Holá, Jan Kotek \\ and Petr Hermann
}

\begin{abstract}
The new ligand $\mathrm{H}_{6}$ do3aPida combines the macrocyclic DOTA-like cavity and the open-chain iminodiacetate group connected through a coordinating phosphinate spacer. Its acid-base and coordination properties in solution were studied by potentiometry. Thermodynamic coordination characteristics of both chelating units are similar to those reported for $\mathrm{H}_{4}$ dota and iminodiacetic acid themselves, respectively, so, macrocyclic and iminodiacetate units behave independently. The formation kinetics of the Ce(III)$\mathrm{H}_{6}$ do3aPida complex was studied by UV-Vis spectrophotometry. Various out-of-cage intermediates were identified with 1:1,1:2 and 2:1 ligand-to-metal ratios. The presence of the strongly coordinating iminodiacetate group significantly slows down the metal ion transfer into the macrocyclic cavity and, so, the formation of the in-cage complex is two orders of magnitude slower than that reported for the Ce(III)$\mathrm{H}_{4}$ dota system. The kinetic inertness of the $\left[\mathrm{Ce}\left(\mathrm{do} 3 \mathrm{P}^{\mathrm{ida}}\right)\right]^{3-}$ complex towards acid-assisted dissociation is comparable to that of the $[\mathrm{Ce}(\mathrm{dota})]^{-}$complex. The coordination modes of the ligand are demonstrated in the solid-state structure of $\left[\mathrm{Cu}_{4}\left(\mathrm{do} 3 \mathrm{a} \mathrm{P}^{\mathrm{ida} a}\right)(\mathrm{OH})\left(\mathrm{H}_{2} \mathrm{O}\right)_{4}\right] \mathrm{Cl} \cdot 7.5 \mathrm{H}_{2} \mathrm{O}$.
\end{abstract}

\section{Introduction}

The macrocyclic ligand $\mathrm{H}_{4}$ dota (Chart 1) and its analogues are used as chelating agents for complexation of various metal ions. The most attention has been focused on lanthanide(III)

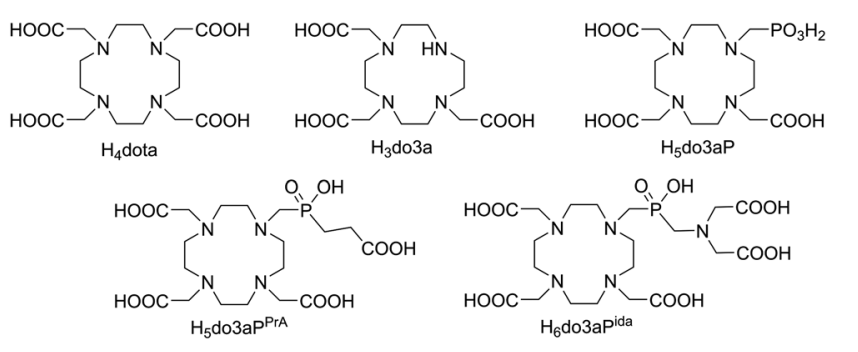

Chart 1 Ligands discussed in the text.

Department of Inorganic Chemistry, Faculty of Science, Charles University, Hlavova 2030, 12840 Prague 2, Czech Republic.E-mail: kubicek@natur.cuni.cz; Fax: +420 221951253; Tel: +420221951436

$\dagger$ Electronic supplementary information (ESI) available: NMR spectra, detailed description and results of potentiometry, distribution diagrams, tables and figures related to solid-state structures, and UV-Vis spectra of the complexes. CCDC 1482406 and 1482407. For ESI and crystallographic data in CIF or other electronic format see DOI: $10.1039 / \mathrm{c} 7 \mathrm{dt} 01797 \mathrm{a}$ complexes as the denticity and size of the cavity in DOTA-like ligands are optimal for these ions. The complexes have found applications mainly in medical imaging techniques, such as Magnetic Resonance Imaging (MRI), Single-Photon Emission Computed Tomography (SPECT), Positron Emission Tomography (PET) or Optical Imaging (OI), and in radiotherapy. ${ }^{1-7}$

The critical point in the applications of DOTA-like complexes in radiomedicine is their complex formation rate. Slow complexation that is typical of macrocyclic ligands becomes the limiting factor mainly while working with short living radioisotopes. The harsh conditions usually used for the lanthanide(III) complexation are often incompatible with biomolecules (e.g. oligopeptides or antibodies) which are used as vectors in the agents currently developed and studied for targeted imaging and therapy. Thus, the improvement of the complexation rate still attracts a lot of attention. The complexation rate is governed by various factors such as the basicity of the macrocycle amino groups, the number and the nature of the pendant arms, the symmetry of the complexes, etc. The complexation of DOTA-like ligands is commonly described as a two-step process. ${ }^{8-14}$ In the first step, the metal ion is swiftly coordinated by the pendant arm oxygen atoms forming an outof-cage complex. In such an intermediate, the macrocycle amino groups are protonated and the rate-determining step of 
the complexation is the deprotonation of the ring nitrogen atoms and the transfer of the metal ion into the central ligand cavity which results in the formation of an in-cage complex with the metal ion coordinated by the four nitrogen and four oxygen atoms. Recently, we have shown that the presence of the phosphonate and/or phosphinate pendants increases the complexation rate in comparison with commonly used carboxylate arms. ${ }^{15-17}$ The group attached to the phosphinate moiety further modifies the complexation rate. The significantly enhanced rate was described for the phosphinates bearing another coordinating (donor) group(s). ${ }^{18-20}$ However, the role of another coordinating group in the pendant arm for the coordination properties of the ligands is not fully understood.

In this work, we report on the synthesis and characterization of a DOTA-like ligand bearing an iminodiacetate (IDA) group attached to the phosphinate pendant arm, $\mathrm{H}_{6} \mathrm{do} 3 \mathrm{aP}^{\mathrm{ida}}$ (Chart 1). The IDA group was chosen as we expected the formation of the out-of-cage complexes with well-defined stoichiometry and sufficient stability so that the results might be easily evaluated. In recent years, several DOTA-like ligands bearing an iminodiacetate group in the pendant arm have been reported as radionuclide carriers, ${ }^{21-25}$ calcium responsive agents $^{26,27}$ or bone targeting ${ }^{28}$ and micellar $^{29}$ luminescent probes. However, the effect of the IDA group on the coordination properties of the ligands has been studied only briefly. Here, we evaluate the formation rate, thermodynamic stability and kinetic inertness of metal complexes with the title ligand with respect to their potential applications in MRI and radiomedicine.

\section{Experimental part}

\section{Materials and methods}

Commercially available chemicals were used as received. $t$ - $\mathrm{Bu}_{3} \mathrm{do} \mathrm{a} \cdot \mathrm{HBr}\left(\mathrm{H}_{3} \mathrm{do} \mathrm{a}=1,4,7,10\right.$-tetraazacyclododecane-1,4,7triacetic acid) was synthesized according to the published procedure. ${ }^{30}{ }^{1} \mathrm{H}$ (400 or $\left.300 \mathrm{MHz}\right),{ }^{13} \mathrm{C}\left(100\right.$ or $75 \mathrm{MHz}$ ) and ${ }^{31} \mathrm{P}$ (162 or $122 \mathrm{MHz}$ ) NMR spectra were acquired at $25^{\circ} \mathrm{C}$ (unless stated otherwise) with Varian Unity Inova-400 and -300 spectrometers, respectively. For the ${ }^{1} \mathrm{H}$ and ${ }^{13} \mathrm{C}$ NMR measurements in $\mathrm{D}_{2} \mathrm{O}$, the methyl signal of $t-\mathrm{BuOH}$ was used as an internal standard $\left(\delta=1.2\right.$ and 31.2 ppm for ${ }^{1} \mathrm{H}$ and ${ }^{13} \mathrm{C} \mathrm{NMR}$, respectively). The ${ }^{31} \mathrm{P}$ chemical shifts were measured with respect to $1 \% \mathrm{H}_{3} \mathrm{PO}_{4}$ in $\mathrm{D}_{2} \mathrm{O}$ as an external reference. ESI-MS spectra were recorded on a Bruker Esquire 3000 spectrometer equipped with an electrospray ion source and ion-trap detection system.

\section{$[N, N$-Bis(carboxymethyl)aminomethyl $]$ phosphinic acid}

Iminodiacetic acid $(5.02 \mathrm{~g}, 38 \mathrm{mmol})$ was suspended in water $(50 \mathrm{ml})$. The mixture was heated at $40{ }^{\circ} \mathrm{C}$ and $50 \%$ aq. $\mathrm{H}_{3} \mathrm{PO}_{2}$ $(24.82 \mathrm{~g}, 188 \mathrm{mmol})$ was added over $10 \mathrm{~min}$. Then, paraformaldehyde (1.25 g, $42 \mathrm{mmol}$ ) was added in small portions over $60 \mathrm{~min}$. The mixture was acidified with conc. aq. $\mathrm{HCl}(0.5 \mathrm{ml})$ and stirred at $40{ }^{\circ} \mathrm{C}$ for $72 \mathrm{~h}$. Then, the solid was filtered off. The crude product was dissolved in a minimum amount of boiling water. The solution was acidified with conc. aq. $\mathrm{HCl}$ $(0.5 \mathrm{ml})$. After standing overnight, the white crystalline solid was filtered off, washed with ethanol and dried over $\mathrm{P}_{2} \mathrm{O}_{5}$, affording $2.8 \mathrm{~g}$ of the product (35\%).

NMR (in $\left.\mathrm{D}_{2} \mathrm{O} / \mathrm{NaOD}, \mathrm{pD} \sim 12\right):{ }^{1} \mathrm{H}: 3.47\left(\mathrm{P}-\mathrm{CH}_{2}-\mathrm{N}, \mathrm{d}, 2 \mathrm{H}\right.$, $\left.{ }^{2} J_{\mathrm{HP}}=10.4 \mathrm{~Hz}\right) ; 4.19\left(\mathrm{~N}-\mathrm{CH}_{2}-\mathrm{CO}_{2} \mathrm{H}, \mathrm{s}, 4 \mathrm{H}\right) ; 7.26(\mathrm{H}-\mathrm{P}, \mathrm{d}, 1 \mathrm{H}$, $\left.{ }^{1} J_{\mathrm{HP}}=553 \mathrm{~Hz}\right) ;{ }^{13} \mathrm{C}\left\{{ }^{1} \mathrm{H}\right\}: 53.7\left(\mathrm{P}-\mathrm{CH}_{2}-\mathrm{N}, \mathrm{d},{ }^{1} J_{\mathrm{CP}}=83 \mathrm{~Hz}\right) ; 57.5$ $\left(\mathrm{N}-\mathrm{CH}_{2}-\mathrm{CO}_{2} \mathrm{H}, \mathrm{s}\right) ; 169.2(\mathrm{COOH}, \mathrm{s}) ;{ }^{31} \mathrm{P}: 11.94$ (d, ${ }^{1} J_{\mathrm{HP}}=553$ Hz). MS: (-) $209.5(\mathrm{M}-\mathrm{H})^{-}$. Elemental analysis: found (calculated for $\left.\mathrm{C}_{5} \mathrm{H}_{10} \mathrm{NO}_{6} \mathrm{P}\right) \mathrm{C}: 28.44$ (28.45), $\mathrm{H}: 4.60$ (4.77), N: 6.54 (6.63), P: 14.48 (14.67).

\section{0-(\{Hydroxy[ $N, N$-bis(carboxymethyl)aminomethyl] phosphoryl $\}$ methyl)-1,4,7,10-tetraazacyclododecane-1,4,7- triacetic acid}

$t \mathrm{Bu}_{3} \mathrm{do} 3 \mathrm{a} \cdot \mathrm{HBr}(3.86 \mathrm{~g}, 6.5 \mathrm{mmol})$ was dissolved in a mixture of trifluoroacetic acid $(40 \mathrm{ml})$ and chloroform $(40 \mathrm{ml})$ and the resulting solution was refluxed for $24 \mathrm{~h}$. Then, volatiles were removed under vacuum. The resulting oily residue was dissolved in water $(20 \mathrm{ml})$, mixed with aq. conc. $\mathrm{HCl}(20 \mathrm{ml})$ and $[N, N$-bis(carboxymethyl)aminomethyl $]$ phosphinic acid $(2.73 \mathrm{~g}$, $13 \mathrm{mmol}$ ) was added. The resulting mixture was heated at $50{ }^{\circ} \mathrm{C}$ and paraformaldehyde $(0.58 \mathrm{~g}, 19 \mathrm{mmol})$ was added in small portions. The reaction mixture was stirred overnight. Volatiles were evaporated on a rotary evaporator. The oily residue was purified on a strong cation exchanger (Dowex 50, $\mathrm{H}^{+}$-form). Impurities were eluted with water and the product was eluted with $5 \%$ aq. ammonia. The product-containing fractions were evaporated and purified on a strong anion exchanger (Dowex 1, acetate form). Impurities were eluted with water followed by $2 \%$ aq. AcOH. The product was eluted with $6 \mathrm{M}$ aq. HCl. Volatiles were evaporated and the oily residue was recrystallized from water by the addition of EtOH. The product was filtered off, washed with EtOH and dried over $\mathrm{P}_{2} \mathrm{O}_{5}$. The product $(2.32 \mathrm{~g}, 63 \%)$ was obtained as a non-stoichiometric hydrate in the form of white powder.

NMR (in $\left.\mathrm{D}_{2} \mathrm{O}, \mathrm{pD}=6\right)$ : ${ }^{1} \mathrm{H}: 3.13$ (cyclen, bs, $\left.4 \mathrm{H}\right), 3.16(\mathrm{P}-$ $\mathrm{C}_{2}$-cyclen, d, $2 \mathrm{H},{ }^{2} J_{\mathrm{HP}}=4.9 \mathrm{~Hz}$ ), 3.25 (cyclen, bs, $\left.4 \mathrm{H}\right), 3.37$ (cyclen- $\left.\underline{\mathrm{H}}_{2}-\mathrm{COOH}, \mathrm{s}, 4 \mathrm{H}\right), 3.41\left(\mathrm{P}-\mathrm{C} \underline{H}_{2}-\mathrm{IDA}, \mathrm{d}, 2 \mathrm{H},{ }^{2} J_{\mathrm{HP}}=7.3\right.$ $\mathrm{Hz}$ ), 3.45 (cyclen, bs, 4H), 3.50 (cyclen, bs, 4H), 3.85 (cyclen$\underline{\mathrm{C}}_{2}-\mathrm{COOH}, \mathrm{s}, 2 \mathrm{H}$ ), 3.92 (IDA- $\underline{\mathrm{H}}_{2}-\mathrm{COOH}, \mathrm{s}, 4 \mathrm{H}$ ); ${ }^{13} \mathbf{C}\left\{{ }^{1} \mathbf{H}\right\}$ : 48.4 (cyclen, s), 49.2 (cyclen, s), 51.1 (cyclen, s), 51.7 (cyclen, s), $52.7\left(\right.$ cyclen $\left.-{ }^{C} \mathrm{H}_{2}-\mathrm{P}, \mathrm{d},{ }^{1} J_{\mathrm{CP}}=98 \mathrm{~Hz}\right), 53.7\left(\mathrm{IDA}-\underline{C H}_{2}-\mathrm{P}, \mathrm{d},{ }^{1} J_{\mathrm{CP}}=\right.$ $79 \mathrm{~Hz}$ ), 55.7 (cyclen- $\left.\mathrm{CH}_{2}-\mathrm{COOH}, \mathrm{s}\right), 56.7$ (cyclen- ${ }_{-} \mathrm{H}_{2}-\mathrm{COOH}$, s), $58.8\left(\right.$ IDA- $\left.{ }_{-} \mathrm{H}_{2}-\mathrm{COOH}, \mathrm{s}\right), 171.9$ (IDA- $\left.\mathrm{CH}_{2}-\underline{\mathrm{COOH}}, \mathrm{s}\right), 172.1$ (cyclen- $\mathrm{CH}_{2}-\underline{-} \mathrm{OOH}, \mathrm{s}$ ), 179.0 (cyclen- $\mathrm{CH}_{2}-\underline{\mathrm{COOH}}, \mathrm{s}$ ); ${ }^{31} \mathbf{P}\left\{{ }^{1} \mathbf{H}\right\}$ : 24.98 (s). ${ }^{1} \mathrm{H},{ }^{13} \mathrm{C}\left\{{ }^{1} \mathrm{H}\right\}$ and ${ }^{31} \mathrm{P}\left\{{ }^{1} \mathrm{H}\right\}$ NMR spectra are shown in Fig. S1.† MS: (-) $568.0(\mathrm{M}-\mathrm{H})^{-}$. Elemental analysis: found (calculated for $\mathrm{C}_{20} \mathrm{H}_{36} \mathrm{~N}_{5} \mathrm{O}_{12} \mathrm{P} \cdot 3.5 \mathrm{H}_{2} \mathrm{O}$ ) C: 37.93 (37.98), H: 6.50 (6.85), N: 10.80 (11.07), P: 4.78 (4.90).

\section{Potentiometric titrations}

The methodology of the potentiometric titrations and processing of the experimental data were analogous to those pre- 
viously reported. ${ }^{17,31}$ For the detailed procedure, see the ESI. $\dagger$ Titrations were carried out in a vessel thermostated at $25 \pm$ $0.1{ }^{\circ} \mathrm{C}$ at ionic strength $I=0.1 \mathrm{M}\left(\mathrm{NMe}_{4}\right) \mathrm{Cl}$. The ligand-tometal ratio was $1: 1$ (and $1: 2$ or $2: 1$ in some cases) with $c_{\mathrm{L}}=$ $4 \mathrm{mM}$, and the $\mathrm{pH}$ range was 1.7-12.0 (or till precipitation of the metal hydroxide). The titrations were carried out at least three times, each consisting of about 40 points. The water ion product, $\mathrm{p} K_{\mathrm{w}}=13.81$, and stability constants of $\mathrm{M}^{2 / 3+}-\mathrm{OH}^{-}$ systems were taken from ref. 32 . The calculated overall protonation constants $\beta_{h}$ are concentration constants and are defined by $\beta_{h}=\left[\mathrm{H}_{h} \mathrm{~L}\right] /\left([\mathrm{H}]^{h} \times[\mathrm{L}]\right)$, and consecutive protonation constants are $\log K(\mathrm{HL})=\log \beta_{1}$ and $\log K\left(\mathrm{H}_{h} \mathrm{~L}\right)=\log \beta_{h}-$ $\log \beta_{h-1}$. The overall stability constants are defined by $\beta_{h l m}=$ $\left[\mathrm{H}_{h} \mathrm{~L}_{l} \mathrm{M}_{m}\right] /\left([\mathrm{H}]^{h} \times[\mathrm{L}]^{l} \times[\mathrm{M}]^{m}\right)$. The constants (with standard deviations) were calculated with the program OPIUM. ${ }^{33}$ Throughout the paper, $\mathrm{pH}$ means $-\log \left[\mathrm{H}^{+}\right]$.

The stability constants of the Ln(III) complexes were obtained by the out-of-cell method. The batches (starting volume $1 \mathrm{ml}$ ) were prepared under an argon stream in tubes with ground joints from the ligand, metal ion and $\mathrm{HCl} /\left(\mathrm{NMe}_{4}\right)$ $\mathrm{Cl}$ stock solutions and water $(\mathrm{L}: \mathrm{M}=1: 0.95$ molar ratio, $\left.c_{\mathrm{L}}=0.004 \mathrm{M}\right)$. Then, the known amount of the $\left(\mathrm{NMe}_{4}\right) \mathrm{OH}$ stock solution was added under Ar. The tubes were firmly closed with stoppers and the solutions were equilibrated at room temperature for 4 weeks (one batch was checked after 6 weeks and gave the same data). The titrations were performed in the $\mathrm{pH}$ range of $1.5-3.8$ (the final $\mathrm{pH}$ values) with around 20 data points per titration and three titrations per system.

The solution of the pre-formed $\mathrm{Ln}$ (III) complexes $(\mathrm{Ln}=\mathrm{La}$, $\mathrm{Nd}, \mathrm{Eu}, \mathrm{Gd}$ and Y) was obtained by mixing a known amount of the ligand ( $5 \%$ molar excess) and $\mathrm{LnCl}_{3}$ stock solutions in a glass ampoule followed by a slow portion-wise addition ( $2 \mathrm{~h}$ ) of stock $\left(\mathrm{NMe}_{4}\right) \mathrm{OH}$ solution (4 equiv.) under $\mathrm{Ar}$, and the ampoule was flame-sealed and left at $80^{\circ} \mathrm{C}$ overnight to fully form the in-cage complexes of the metal ions. The ampoule was opened under $\mathrm{Ar}$ and the aliquots of the in-cage$\left[\mathrm{Ln}\left(\mathrm{do} 3 \mathrm{aP}^{\mathrm{ida}}\right)\right]^{3-}$ complex solutions were transferred into the titration vessel. Water, $\mathrm{HCl}$ and $\left(\mathrm{NMe}_{4}\right) \mathrm{Cl}$ stock solutions (and in the case of the Gd(III) complex, also stock solutions of other metal chlorides) were added (to reach pH of about 1.8 and $I=$ $0.1 \mathrm{M}(\mathrm{H}, \mathrm{NMe} 4) \mathrm{Cl}$ in the final solution, starting volume $5 \mathrm{~mL}$, complex concentration $\sim 0.004 \mathrm{M}$ ) and the in-cell titration was performed as above.

\section{Kinetic studies}

The experiments were carried out in the $\mathrm{pH}$ range of 3.5-9.0 at the temperature $25 \pm 0.1{ }^{\circ} \mathrm{C}$ maintained by the Peltier block employing a spectrophotometer Specord 50 Plus (Analytik Jena AG). The kinetics was studied in $1 \mathrm{~cm}$ sample cells using the following non-coordinating buffers $(c=0.2 \mathrm{M})$ : 1,4-dimethylpiperazine $(\mathrm{pH}<5)$, acetic acid ( $\mathrm{pH} 5-5.5)$, MES ( $\mathrm{pH}$ 5.6-6.8; MES = 2-( $N$-morpholino)ethanesulfonic acid), HEPES $(\mathrm{pH}$ 6.8-8.2; HEPES = 2-[4-(2-hydroxyethyl)piperazin-1-yl] ethanesulfonic acid) and AMPSO ( $\mathrm{pH}$ 8.3-9.0; AMPSO $=\mathrm{N}$-(1,1-dimethyl2-hydroxyethyl)-3-amino-2-hydroxypropanesulfonic acid). The time dependence of absorbance at $314 \mathrm{~nm}$ was fitted with the general exponential function (eqn (1))

$$
A=A_{\mathrm{f}}+\left(A_{0}-A_{\mathrm{f}}\right) \cdot \mathrm{e}^{-k_{\mathrm{obs}} \cdot t}
$$

where $A$ is absorbance, $A_{\mathrm{f}}$ is the final absorbance, $A_{0}$ is the initial absorbance, $t$ is time and $k_{\text {obs }}$ is the rate constant of the reaction. The data were fitted by means of a least square fitting procedure using the Micromath Scientist program version 2.0 (Salt Lake City, UT, USA).

Formation kinetics of the in-cage Ce(III) complex was followed in the wavelength region of $270-360 \mathrm{~nm}$ using the $\mathrm{pH}$ range of 3.5-9 and the concentration ranges $c_{\mathrm{Ce}}=5.0 \times 10^{-4}$ $7.5 \times 10^{-3} \mathrm{M}$ and $c_{\mathrm{L}}=5.0 \times 10^{-4}-5.0 \times 10^{-3} \mathrm{M}$. The experiments were initiated by the addition of the Ce(III) stock solution into the cell and the data acquisition started after $15 \mathrm{~s}$ dead time. The formation of the out-of-cage complex was monitored by obtaining UV-Vis spectra in the wavelength region of 270-360 nm immediately after mixing of the metal ion, ligand and stock buffer solutions $\left(c_{\mathrm{Ce}}=2.5 \times 10^{-3} \mathrm{M}, c_{\mathrm{L}}=0-5 \times 10^{-3}\right.$ M, pH 4 and 8).

Dissociation kinetics of the in-cage $\left[\mathrm{Ce}\left(\mathrm{do} 3 \mathrm{aP}^{\mathrm{ida}}\right)\right]^{3-}$ complex $\left(c=2.5 \times 10^{-3} \mathrm{M}\right)$ was studied in $\mathrm{HClO}_{4}(c=0.2-3.0$ $\mathrm{M})$. The ionic strength was maintained by the addition of $\mathrm{NaClO}_{4}\left(I=3 \mathrm{M}(\mathrm{H} / \mathrm{Na}) \mathrm{ClO}_{4}\right)$.

\section{X-ray diffraction studies}

Single crystals of $\mathrm{H}_{6}$ do3aP $\mathrm{P}^{\mathrm{ida}} \cdot 4 \mathrm{H}_{2} \mathrm{O}$ were obtained by a slow diffusion of EtOH vapour into an aq. solution of the ligand. Single crystals of $\left[\mathrm{Cu}_{4}\left(\mathrm{do} 3 \mathrm{aP}^{\mathrm{ida}}\right)(\mathrm{OH})\left(\mathrm{H}_{2} \mathrm{O}\right)_{4}\right] \mathrm{Cl} \cdot 7.5 \mathrm{H}_{2} \mathrm{O}$ were obtained by a slow diffusion of $\mathrm{EtOH}$ vapour into an aq. solution containing ligand and $\mathrm{CuCl}_{2}$ (5 equiv.) adjusted to $\mathrm{pH} 4.1$ by the addition of LiOH.

The diffraction data were collected at $150 \mathrm{~K}$ (Cryostream Cooler, Oxford Cryosystem) using a Nonius Kappa CCD diffractometer and $\mathrm{Mo}-\mathrm{K}_{\alpha}$ radiation $(\lambda=0.71073 \AA)$ and analysed using the HKL DENZO program package. ${ }^{34}$ The structures were solved by direct methods (SIR92), ${ }^{35}$ and refined by full-matrix least-squares techniques (SHELXL2014). ${ }^{36}$ In general, all nonhydrogen atoms were refined anisotropically. All hydrogen atoms were located in the difference map of electron density; however, they were fixed in theoretical $(\mathrm{C}-\mathrm{H})$ or original $(\mathrm{N}-\mathrm{H}, \mathrm{O}-\mathrm{H})$ positions with thermal parameters $U_{\text {eq }}(\mathrm{H})=1.2 U_{\text {eq }}(\mathrm{X})$ as their free refinement led to some unrealistic bond lengths. In the structure of $\mathrm{H}_{6} \mathrm{do} 3 \mathrm{aP}^{\mathrm{ida}} \cdot 4 \mathrm{H}_{2} \mathrm{O}$, one of the water molecules was found to be disordered in two positions (one of them very close to the centre of symmetry) and was best refined with restrained occupancy of both positions $50: 50 \%$. In the structure of $\left[\mathrm{Cu}_{4}\left(\mathrm{do} 3 \mathrm{aP}^{\mathrm{ida}}\right)(\mathrm{OH})\left(\mathrm{H}_{2} \mathrm{O}\right)_{4}\right] \mathrm{Cl} \cdot 7.5 \mathrm{H}_{2} \mathrm{O}$, the chloride anion was best refined disordered over three positions very close to each other; the relative occupancies of these positions were chosen to obtain comparable thermal parameters of all three atomic fragments, and were $50: 35: 15 \%$; it was possible to use anisotropic refinement for all three positions. One of the water molecules lies very close to the centre of symmetry and, thus, its occupancy factor was set to $50 \%$. Table S6† con- 
tains selected crystallographic parameters for the structures reported in this paper. Complete data for the structures have been deposited with the Cambridge Crystallographic Data Centre as CCDC 1482406 and 1482407.†

\section{Results and discussion}

\section{Ligand synthesis}

A precursor of the phosphinate pendant arm of the designed ligand was prepared by reaction of iminodiacetic acid with hypophosphorous acid and paraformaldehyde at $40{ }^{\circ} \mathrm{C}$ using a modified procedure. ${ }^{37}$ The resulting $[N, N$-bis(carboxymethyl) aminomethyl]phosphinic acid was consequently reacted with $\mathrm{H}_{3} \mathrm{do} 3 \mathrm{a}$ (prepared in situ from $t \mathrm{Bu}_{3} \mathrm{do3a}$ ) and paraformaldehyde at $50{ }^{\circ} \mathrm{C}$. The title compound was purified by ion exchange chromatography, isolated in its hexaprotonated zwitterionic form and finally crystallized from water by addition of EtOH. The solid-state structure of the ligand was determined by X-ray diffraction (Fig. 1). In the hexaprotonated ligand mole-

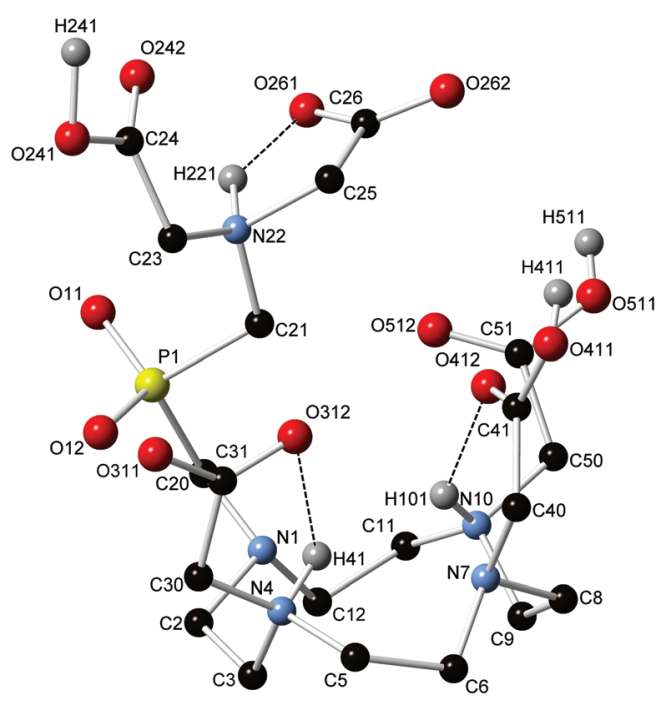

Fig. 1 The molecular structure of $\mathrm{H}_{6}$ do3a $\mathrm{P}^{\text {ida }}$ found in the solid-state structure of $\mathrm{H}_{6}$ do3aPida. $4 \mathrm{H}_{2} \mathrm{O}$. The hydrogen atoms attached to the carbon atoms are not displayed for the clarity reasons. The dashed lines represent intramolecular hydrogen bonds. The data were collected at $150 \mathrm{~K}$. cule, two protons are bound to macrocycle nitrogen atoms as it is common for other cyclen-based ligands, forming the conformation of the macrocycle stabilized by intramolecular hydro-

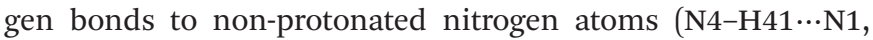
$3.018 \AA$ and $102^{\circ}$; N4-H41 $\cdots \mathrm{N} 7,2.884 \AA$ and $114^{\circ}$; $\mathrm{N} 10-\mathrm{H} 101 \cdots \mathrm{N} 1,3.016 \AA$ and $105^{\circ}$; N10-H101 $\cdots \mathrm{N} 7,3.000 \AA$ and $109^{\circ}$, for donor-acceptor distances and bond angles on the $\mathrm{H}$-vertex, respectively) and pendant carboxylate oxygen atoms

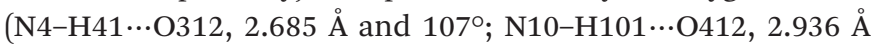
and $133^{\circ}$ ). Another proton is bound to the nitrogen atom of the IDA group that also forms an intramolecular hydrogen bond with one of the IDA acetate moieties (N22-H221‥O261, $2.652 \AA, 143^{\circ}$ ). The remaining three protons are bound to the carboxylate oxygen atoms - one of the IDA acetate groups (O241; involved in strong hydrogen bonding to the macrocyclebound pendant from the neighbouring molecule, see below), and two of the acetate pendants (O411 and O511) bound to the macrocycle backbone (Fig. 1). Two molecules of $\mathrm{H}_{6} \mathrm{do} 3 \mathrm{aP}{ }^{\text {ida }}$ are connected to the centrosymmetric head-to-head dimer through very short intermolecular hydrogen bonds $\left(d_{\mathrm{O} \cdots \mathrm{O}}=\right.$ $2.510 \AA$ ) between protonated IDA-carboxylate (O241) and one of the non-protonated carboxylate pendants bound to the macrocycle from the neighbouring molecule (O311). Such hydrogen bonding is reflected by the relatively long $\mathrm{C}-\mathrm{O}$ bonds of both the involved oxygen atoms (1.264 and $1.309 \AA$ for O241 and $\mathrm{O} 311$, respectively) and by the long distance of the related hydrogen atom from both oxygen atoms (1.219 and $1.342 \AA$, respectively).

\section{Equilibrium data}

The ligand contains two coordination centres, the DOTA-like macrocycle motif and the IDA-phosphinate moiety. To understand the properties of the ligand, information on how the parts communicate with each other is useful. Thus, the solution properties of the title ligand were studied by potentiometry. Seven protonation constants were determined (Tables 1 and $\mathrm{S} 1 \dagger)$. Three protonations take place in the alkaline region and they correspond to the protonation of nitrogen atoms. The remaining four protonation constants lie in the acidic region and they correspond to the protonation of the carboxylate groups. The $\mathrm{pH}$ dependence of the ${ }^{1} \mathrm{H}$ NMR shifts of the acetate $\mathrm{CH}_{2}$ groups (Fig. 2) indicates that the constant $K_{3}\left(\log K_{3}=8.13\right)$ describes the protonation of the amine in the

Table 1 Consecutive protonation constants of the discussed ligands and the pre-formed $\left[\operatorname{Ln}\left(\mathrm{do} 3 \mathrm{aP}{ }^{\mathrm{ida}}\right)\right]^{3-} \operatorname{complexes}\left(25^{\circ} \mathrm{C}, I=0.1 \mathrm{M}(\mathrm{NMe} 4) \mathrm{Cl}\right)$

\begin{tabular}{|c|c|c|c|c|c|}
\hline Constant & $\mathrm{H}_{6} \mathrm{do} 3 \mathrm{aP}^{\text {ida } a}$ & $\mathrm{H}_{4} \mathrm{dota}^{38}$ & $\mathrm{H}_{5} \mathrm{do} 3 \mathrm{aP}^{\operatorname{PrA} 39,42}$ & {$\left[\operatorname{Ln}\left(\operatorname{do} 3 \mathrm{aP} \mathrm{P}^{\mathrm{ida}}\right)\right]^{3-a, b}$} & $\mathrm{H}_{2} \mathrm{ida}^{43}$ \\
\hline $\log K_{1}$ & 12.85 & 12.93 & 12.68 & $7.67-7.95$ & 9.32 \\
\hline $\log K_{2}$ & 9.63 & 9.72 & 9.44 & $2.40-2.74$ & 2.60 \\
\hline $\log K_{4}$ & 4.40 & 4.15 & 4.34 & - & - \\
\hline $\log K_{5}$ & 3.27 & 2.29 & 2.94 & - & - \\
\hline $\log K_{6}$ & 1.98 & 1.34 & 1.54 & - & - \\
\hline $\log K_{7}$ & 1.58 & - & - & - & - \\
\hline
\end{tabular}

${ }^{a}$ For overall equilibrium constants with experimental errors, see the ESI. ${ }^{b}$ Determined for pre-formed complexes with La(III), Nd(III), Eu(III), Gd(III) and $\mathrm{Y}(\mathrm{III})$ ions. 


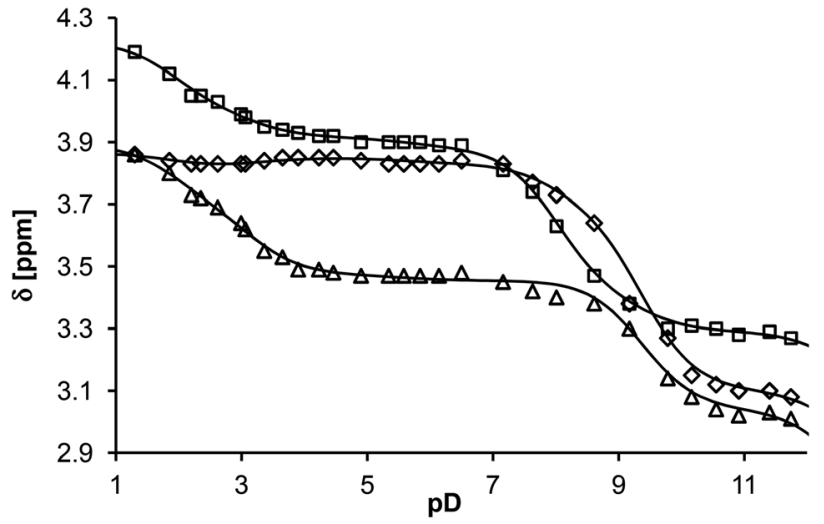

Fig. $2{ }^{1} \mathrm{H}$ NMR titration of the acetate $\mathrm{CH}_{2}$ groups of $\mathrm{H}_{6}$ do3aPida (diamonds and triangles - the DO3A group; squares - IDA group; $25^{\circ} \mathrm{C}$ ).

IDA group and constants $K_{1}$ and $K_{2}$ correspond to the protonation of the macrocycle nitrogen atoms. All the protonations are reflected in the ${ }^{31} \mathrm{P}$ NMR titration curve (Fig. $\mathrm{S} 2 \dagger$ ) as the chemical shift gradually changes along the whole $\mathrm{pH}$ region of 7-10. The values of $K_{1}$ and $K_{2}$ are comparable to those of $\mathrm{H}_{4} \mathrm{dota}^{38}$ or its monophosphinate analogues (e.g. $\left.\mathrm{H}_{5} \mathrm{do} 3 \mathrm{aP}^{\mathrm{PrA}}\right){ }^{39}$ The assignment of the constant $K_{3}$ to the IDA moiety is supported also by the measurements of the first protonation constants of the pre-formed $\left[\operatorname{Ln}\left(\mathrm{do} 3 \mathrm{aP}^{\mathrm{ida}}\right)\right]^{3-}$ complexes $\left(\log K_{1}=7.67-7.95\right.$, Tables 1, 2 and $\mathrm{S} 1 \dagger$ ). In these complexes, the metal ion is bound in the macrocyclic cavity, and only the IDA group can be protonated. The protonation constant of this nitrogen atom is very similar (only slightly lower due to the charge effect of the central metal ion) to the value of the constant $K_{3}$ of the free $\mathrm{H}_{6} \mathrm{do} 3 \mathrm{aP}^{\mathrm{ida}}$. Compared to iminodiacetic acid itself, the constants of its phosphinic derivatives are by more than one order lower due to the electron withdrawing effect of the phosphinate group $(\mathrm{s}) .^{40,41}$

The complexation of $\mathrm{Cu}$ (II) and $\mathrm{Zn}$ (II) ions was studied by the standard potentiometric in-cell method at the $1: 1$ and 1:2 ligand-to-metal ratio. Both systems behave similarly and an analogous set of stability constants can be calculated (Table S2 $\dagger$ ). Under equimolar conditions, $[\mathrm{M}(\mathrm{L})]$ and $[\mathrm{M}(\mathrm{HL})]$ species are dominant in alkaline and neutral regions, respect- ively (Fig. 3A). Values of the stability constants (Table 2) are higher by about one order in magnitude than those reported for $\mathrm{H}_{4}$ dota (Table $\mathrm{S} 3 \dagger$ ). It indicates that the metal ions are in $[\mathrm{M}(\mathrm{L})]$ species coordinated in the macrocyclic cavity. The mixture of the protonated species was identified in the acid region. Protons are bound to the IDA nitrogen atom or to noncoordinated carboxylates. The fact that only one carboxylate protonation was found for the $\mathrm{Cu}$ (II) complex indicates the coordination of two macrocycle carboxylate pendant arms, whereas the phosphinic group remains free. Similar coordination mode was found in the solid state (see below). Surprisingly, high abundance of the dinuclear complexes was found in the acid region even in solution with $\mathrm{M}: \mathrm{L}=$ 1:1 molar ratio. The presence of the dinuclear complexes under equimolar conditions could be explained by changes of the charge-distribution associated with the coordination of the first metal ion. At low pH, the macrocyclic part is protonated on nitrogen atoms as well as on carboxylates. So, more than two protons dissociate due to the in-cage coordination of the metal ion. In the case of divalent ions, complexation leads to a decrease of the overall positive charge of the whole complex species. Consequently, coordination of the second metal ion by the IDA group is facilitated. Under the metal ion excess, dinuclear complexes are dominant along the whole $\mathrm{pH}$ range (Fig. 3B). As one ligand molecule does not saturate the coordination sphere of both metal ions in the dinuclear species, hydroxido-complexes are formed in the alkaline region.

The complexation of the $\operatorname{Ln}(\mathrm{III})$ ions is slow and, therefore, the systems were studied by the out-of-cell method in the acidic region. The out-of-cell titrations cannot be performed at $\mathrm{pH}>5$ due to the precipitation of lanthanide(III) hydroxides. However, at $\mathrm{pH}<5$, only protonated complexes $\left[\mathrm{Ln}\left(\mathrm{H}_{3} \mathrm{~L}\right)\right]$, $\left[\mathrm{Ln}\left(\mathrm{H}_{2} \mathrm{~L}\right)\right]^{-}$and $[\mathrm{Ln}(\mathrm{HL})]^{2-}$ (although in in-cage binding mode, see below) are formed and, thus, full description of the systems was enabled only with the knowledge of the values of the first protonation constants (corresponding to the formation of $[\operatorname{Ln}(\mathrm{HL})]^{2-}$ ) belonging to the IDA moiety. Therefore, the acid-base titration of the pre-formed complex was performed, the protonation constant of $[\operatorname{Ln}(\mathrm{L})]^{3-}$ species was calculated and, consequently, the stability constant of the $[\operatorname{Ln}(\mathrm{L})]^{3-}$ complex was derived. As the systems were not studied in metal ion excess

Table 2 Equilibrium constants of the $\mathrm{H}_{6}$ do3aPida complexes $\left(25^{\circ} \mathrm{C}, I=0.1 \mathrm{M}\left(\mathrm{NMe}_{4}\right) \mathrm{Cl}\right)^{a}$

\begin{tabular}{|c|c|c|c|c|c|c|c|}
\hline Equilibrium $^{b}$ & $\mathrm{Cu}(\mathrm{II})$ & $\mathrm{Zn}(\mathrm{II})$ & $\mathrm{La}(\mathrm{III})$ & $\mathrm{Nd}(\mathrm{III})$ & $\operatorname{Eu}(\mathrm{III})$ & $\mathrm{Gd}(\mathrm{III})$ & $\mathrm{Y}(\mathrm{III})$ \\
\hline $\mathrm{M}+\mathrm{L}=[\mathrm{M}(\mathrm{L})]$ & 23.75 & 21.79 & 22.09 & 24.02 & 24.94 & 25.27 & 25.39 \\
\hline$[\mathrm{M}(\mathrm{HL})]=[\mathrm{M}(\mathrm{L})]+\mathrm{H}^{+}$ & 8.40 & 8.46 & $7.67^{c}$ & $7.83^{c}$ & $7.83^{c}$ & $7.79^{c}$ & $7.95^{c}$ \\
\hline$\left[\mathrm{M}\left(\mathrm{H}_{2} \mathrm{~L}\right)\right]=[\mathrm{M}(\mathrm{HL})]+\mathrm{H}^{+}$ & 3.84 & 3.76 & $3.20 / 2.58^{c}$ & $2.94 / 2.46^{c}$ & $2.95 / 2.40^{c}$ & $2.60 / 2.74^{c}$ & $2.40 / 2.57^{c}$ \\
\hline$\left[\mathrm{M}\left(\mathrm{H}_{3} \mathrm{~L}\right)\right]=\left[\mathrm{M}\left(\mathrm{H}_{2} \mathrm{~L}\right)\right]+\mathrm{H}^{+}$ & - & 2.98 & $2.23 / 1.63^{c}$ & $2.22 / 1.51^{c}$ & $2.27 / 1.59^{c}$ & $2.13 / 1.56^{c}$ & $2.20 / 1.77^{c}$ \\
\hline $\mathrm{M}+[\mathrm{M}(\mathrm{L})]=\left[\mathrm{M}_{2}(\mathrm{~L})\right]$ & 10.96 & 9.59 & $d$ & $d$ & $d$ & $d$ & $d$ \\
\hline$\left[\mathrm{M}_{2}(\mathrm{HL})\right]=\left[\mathrm{M}_{2}(\mathrm{~L})\right]+\mathrm{H}^{+}$ & 4.00 & 3.68 & $d$ & $d$ & $d$ & $d$ & $d$ \\
\hline$\left[\mathrm{M}_{2}\left(\mathrm{H}_{2} \mathrm{~L}\right)\right]=\left[\mathrm{M}_{2}(\mathrm{HL})\right]+\mathrm{H}^{+}$ & 1.59 & - & $d$ & $d$ & $d$ & $d$ & $d$ \\
\hline$\left[\mathrm{M}_{2}(\mathrm{~L})\right]+\mathrm{H}_{2} \mathrm{O}=\left[\mathrm{M}_{2}(\mathrm{~L})(\mathrm{OH})\right]+\mathrm{H}^{+}$ & 9.20 & 10.17 & $d$ & $d$ & $d$ & $d$ & $d$ \\
\hline$\left[\mathrm{M}_{2}(\mathrm{~L})(\mathrm{OH})\right]+\mathrm{H}_{2} \mathrm{O}=\left[\mathrm{M}_{2}(\mathrm{~L})(\mathrm{OH})_{2}\right]+\mathrm{H}^{+}$ & 12.05 & - & $d$ & $d$ & $d$ & $d$ & $d$ \\
\hline
\end{tabular}

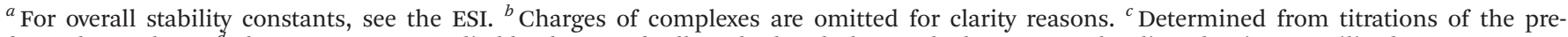
formed complexes. ${ }^{d}$ The systems were studied by the out-of-cell method and, thus, only the $1: 1$ metal-to-ligand ratio was utilized. 

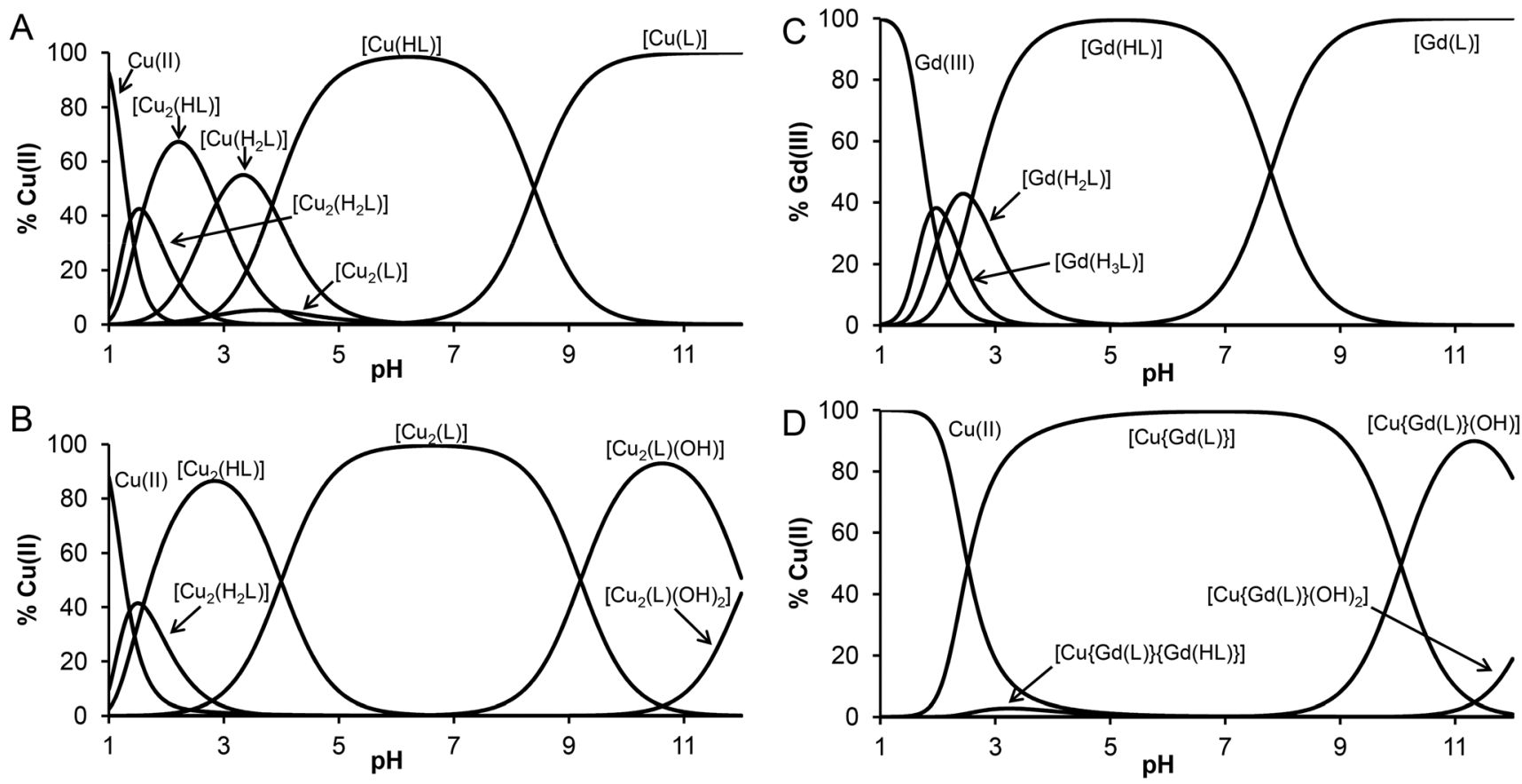

Fig. 3 Distribution diagrams of the $\mathrm{Cu}(\mathrm{II})-\mathrm{H}_{6}$ do3aP ${ }^{\text {ida }}$ system at $1: 1$ (A) and $1: 2$ (B) ligand-to-metal ratios, Gd(III)- $\mathrm{H}_{6}$ do3aP ${ }^{\text {ida }}$ system at $1: 1$ ratio $(\mathrm{C})$ and the ternary system $\mathrm{Cu}(\mathrm{II})$-preformed $\left[\mathrm{Gd}\left(\mathrm{do} 3 \mathrm{aP} \mathrm{P}^{\mathrm{ida}}\right)\right]^{3-}$ at the $1: 1$ ratio $(\mathrm{D})\left(25^{\circ} \mathrm{C}, I=0.1 \mathrm{M}\left(\mathrm{NMe}_{4}\right) \mathrm{Cl}, \mathrm{C}_{\mathrm{L}}=4 \mathrm{mM}\right)$.

(metal hydroxide precipitation), only stability constants of the $1: 1$ complexes were obtained (Table 2). The stabilities of the complexes are slightly higher than those reported for $\mathrm{H}_{4}$ dota (Table S3†). The complexes are present in the protonated form at $\mathrm{pH}<7$ (Fig. 3C). Similarly to transition metal ion complexes, comparison of the stability constants with those of the complexes of the similar ligands (Table $\mathrm{S} 3 \dagger$ ) indicates that the $\left[\operatorname{Ln}\left(\mathrm{H}_{n} \mathrm{do}_{\mathrm{a}} \mathrm{P}^{\mathrm{ida}}\right)\right]^{n-3}$ complexes $(n=0,1)$ are in-cage species with the metal ions bound inside the macrocyclic cavity.

The presence of two different chelating centres allows the formation of heterodinuclear complexes. The coordination of $\mathrm{Cu}$ (II), $\mathrm{Zn}$ (II), $\mathrm{Ca}$ (II) and $\mathrm{Eu}$ (III) ions only by the IDA pendant arm was studied using the pre-formed $\left[\mathrm{Gd}\left(\mathrm{do} 3 \mathrm{aP}^{\text {ida }}\right)\right]^{3-}$ complex. Lanthanide(III) complexes of the title ligand show a high kinetic inertness (see below) and, therefore, the preformed complex could be considered as an intact unit during the course of in-cell potentiometic titrations and the coordination behaviour of the IDA-phosphinate moiety can be evaluated independently. The results are summarized in Table 3. The complexes with $\mathrm{M}:\{\mathrm{Gd}(\mathrm{L})\} 1: 1$ stoichiometry are formed under the equimolar conditions (Fig. 2D, S3 and S4 $\dagger$ ) and the complexes with $\mathrm{M}:\{\mathrm{Gd}(\mathrm{L})\} \quad 1: 2$ stoichiometry are formed when the $\left[\mathrm{Gd}\left(\mathrm{do} 3 \mathrm{aP}^{\mathrm{ida}}\right)\right]^{3-}$ complex was used in excess (Fig. S3 and $\mathrm{S} 4 \dagger)$. The first and the second consecutive stability constants describing the coordination of the $\left[\mathrm{Gd}\left(\mathrm{do} 3 \mathrm{aP}^{\text {ida }}\right)\right]^{3-}$ unit to the $\mathrm{Eu}(\mathrm{III})$ ion are comparable, whereas the coordination of the second $\left[\mathrm{Gd}\left(\mathrm{do} 3 \mathrm{aP}^{\text {ida }}\right)\right]^{3-}$ unit to $\mathrm{Cu}(\mathrm{II})$ or $\mathrm{Zn}$ (II) (already bound in $\left[\mathrm{M}\left\{\mathrm{Gd}\left(\mathrm{do} 3 \mathrm{aP}^{\text {ida }}\right)\right\}\right]^{-}$species $)$is more disfavoured due to the smaller size and lower positive charge of these ions. As the coordination spheres of the metal ions are not saturated, hydroxido complex species are formed in the alkaline region. The formation of the hydroxido complex in the system with

Table 3 Equilibrium constants of the metal ion- $\left[\mathrm{Gd}\left(\mathrm{do} 3 \mathrm{aP}^{\mathrm{ida}}\right)\right]^{3-}$ ternary complexes $\left.\left(25^{\circ} \mathrm{C}, I=0.1 \mathrm{M}(\mathrm{NMe})_{4}\right) \mathrm{Cl}\right)$

\begin{tabular}{|c|c|c|c|c|}
\hline Equilibrium $^{a}$ & $\mathrm{Cu}(\mathrm{II})$ & $\mathrm{Zn}(\mathrm{II})$ & $\mathrm{Ca}(\mathrm{II})$ & $\mathrm{Eu}(\mathrm{III})$ \\
\hline$[\mathrm{M}\{\mathrm{Gd}(\mathrm{HL})\}]=[\mathrm{M}\{\mathrm{Gd}(\mathrm{L})\}]+\mathrm{H}^{+}$ & - & - & - & 2.59 \\
\hline$[\mathrm{M}\{\mathrm{Gd}(\mathrm{L})\}(\mathrm{OH})]+\mathrm{H}_{2} \mathrm{O}=\left[\mathrm{M}\{\mathrm{Gd}(\mathrm{L})\}(\mathrm{OH})_{2}\right]+\mathrm{H}^{+}$ & 11.62 & $b$ & - & $b$ \\
\hline$[\mathrm{Gd}(\mathrm{L})]+[\mathrm{M}\{\mathrm{Gd}(\mathrm{L})\}]=\left[\mathrm{M}\{\mathrm{Gd}(\mathrm{L})\}_{2}\right]$ & 4.87 & 5.20 & - & 7.33 \\
\hline$[\mathrm{Gd}(\mathrm{HL})]+[\mathrm{M}\{\mathrm{Gd}(\mathrm{L})\}]=[\mathrm{M}\{\mathrm{Gd}(\mathrm{HL})\}\{\mathrm{Gd}(\mathrm{L})\}]$ & 2.63 & 2.58 & - & 3.84 \\
\hline$[\mathrm{M}\{\mathrm{Gd}(\mathrm{HL})\}\{\mathrm{Gd}(\mathrm{L})\}]=\left[\mathrm{M}\{\mathrm{Gd}(\mathrm{L})\}_{2}\right]+\mathrm{H}^{+}$ & 5.55 & 5.17 & - & 4.30 \\
\hline
\end{tabular}

${ }^{a}$ Charges of the complexes are omitted for clarity reasons. ${ }^{b}$ The constant cannot be determined due to the precipitation of metal hydroxide in the neutral region when metal excess was used. 
$\mathrm{Ca}$ (II) ions might be explained by the dissociation of the proton from the water molecule coordinated to the Gd(III) ion that is facilitated by the $\mathrm{Ca}(\mathrm{II})$ ion coordinated in the proximity. The stability constants are similar to or slightly higher than those reported for the parent ligand, $\mathrm{H}_{2}$ ida (Table $\mathrm{S} 5 \dagger$ ), despite the lower basicity of the nitrogen atom in the $\left[\mathrm{Gd}\left(\mathrm{do} 3 \mathrm{aP}^{\mathrm{ida}}\right)\right]^{3-}$ complex. It originates from the higher denticity of the IDA-phosphinate coordination site, where the phosphinate group could be coordinated to both metal ions in the bridging mode. Thus, the IDA-phosphinate moiety behaves as a tetradentate ligand even if the phosphinate group is already bound to the metal ion which is located inside the macrocyclic cavity.

The values of protonation and stability constants show that both coordination sites - DOTA-like macrocycle and IDA-phosphinate - behave similarly to the parent ligands, $\mathrm{H}_{4}$ dota and $\mathrm{H}_{2}$ ida, respectively, and almost independently of each other, despite the presence of the very short and mutually shared spacer (Tables S3 and S5†).

\section{Solid-state structure of the $\mathrm{Cu}(\mathrm{II})$ complex}

Despite the numerous attempts to crystallize the $\mathrm{Cu}(\mathrm{II})-$ $\mathrm{H}_{6} \mathrm{do}_{\mathrm{a}} \mathrm{P}^{\mathrm{ida}}$ system, single-crystals suitable for the X-ray diffraction study were obtained only when the ligand was crystallized in the presence of a high excess of $\mathrm{Cu}(\mathrm{II})$ ions. The independent unit of the formed crystals has the composition $\left[\mathrm{Cu}_{4}\left(\mathrm{do} 3 \mathrm{aP}^{\mathrm{ida}}\right)(\mathrm{OH})\left(\mathrm{H}_{2} \mathrm{O}\right)_{4}\right] \mathrm{Cl} \cdot 7.5 \mathrm{H}_{2} \mathrm{O}$, but two asymmetric units form a centrosymmetric dimer with the overall formula $\left[\mathrm{Cu}_{8}\left(\mathrm{do} 3 \mathrm{aP}^{\text {ida }}\right)_{2}(\mathrm{OH})_{2}\left(\mathrm{H}_{2} \mathrm{O}\right)_{8}\right] \mathrm{Cl}_{2} \cdot 15 \mathrm{H}_{2} \mathrm{O}$. The structure of the complex dimer is shown in Fig. 4 and coordination distances are summarized in Table $57 . \dagger$ Each of the four symmetrically independent $\mathrm{Cu}$ (II) ions exhibits different ligand coordination modes. The $\mathrm{Cu} 1$ ion is coordinated in the macrocyclic cavity (Fig. S5 $\dagger$ ) and its coordination mode is analogous to that in the $\mathrm{Cu}(\mathrm{II})$ complexes of $\mathrm{H}_{4}$ dota and related ligands. ${ }^{2}$ The central metal ion is coordinated by four nitrogen atoms of the macrocycle and two oxygen atoms of the acetate pendants, forming a cis $-\mathrm{N}_{4} \mathrm{O}_{2}$ coordination environment. However, one of the oxygen atoms is coordinated with a relatively long distance (2.49 ̊) and, thus, the complex geometry could be alternatively viewed also as a deformed square pyramid. In addition, the detailed coordination geometry in $\left[\mathrm{Cu}\left(\mathrm{do} 3 \mathrm{aP}^{\mathrm{ida}}\right)\right]^{4-}$ is somewhat different from those previously reported in the octahedral structures of $\mathrm{Cu}(\mathrm{II})$ complexes with $\mathrm{H}_{4} \mathrm{dota}^{44-47}$ and related ligands ${ }^{48-50}$ where the coordination sphere was usually axially elongated with the $\mathrm{N}_{2} \mathrm{O}_{2}$ equatorial base (typical equatorial bond lengths around $d_{\mathrm{Cu}-\mathrm{N}} \sim 2.0-2.1 \AA$ and $\left.d_{\mathrm{Cu}-\mathrm{O}} \sim 1.9-2.0 \AA\right)$ and the remaining two nitrogen atoms of the macrocycle coordinated in more distant axial positions $\left(d_{\mathrm{Cu}-\mathrm{N}} \sim 2.3 \AA\right)$. In contrast, all nitrogen atoms in the $\left[\mathrm{Cu}\left(\mathrm{do} 3 \mathrm{aP}^{\mathrm{ida}}\right)\right]^{4-}$ unit are coordinated with short bond distances in a narrow range of 2.06-2.10 $\AA$, and both cis-oxygen atoms of two acetate pendants are bound in more distant positions (2.22 and $2.49 \AA$ ). The $\mathrm{Cu} 2$ ion is coordinated in the square-planar environment with two additional very weak axial interactions (Fig. S6†). The nitrogen atom and both IDA carboxylates are coordinated in
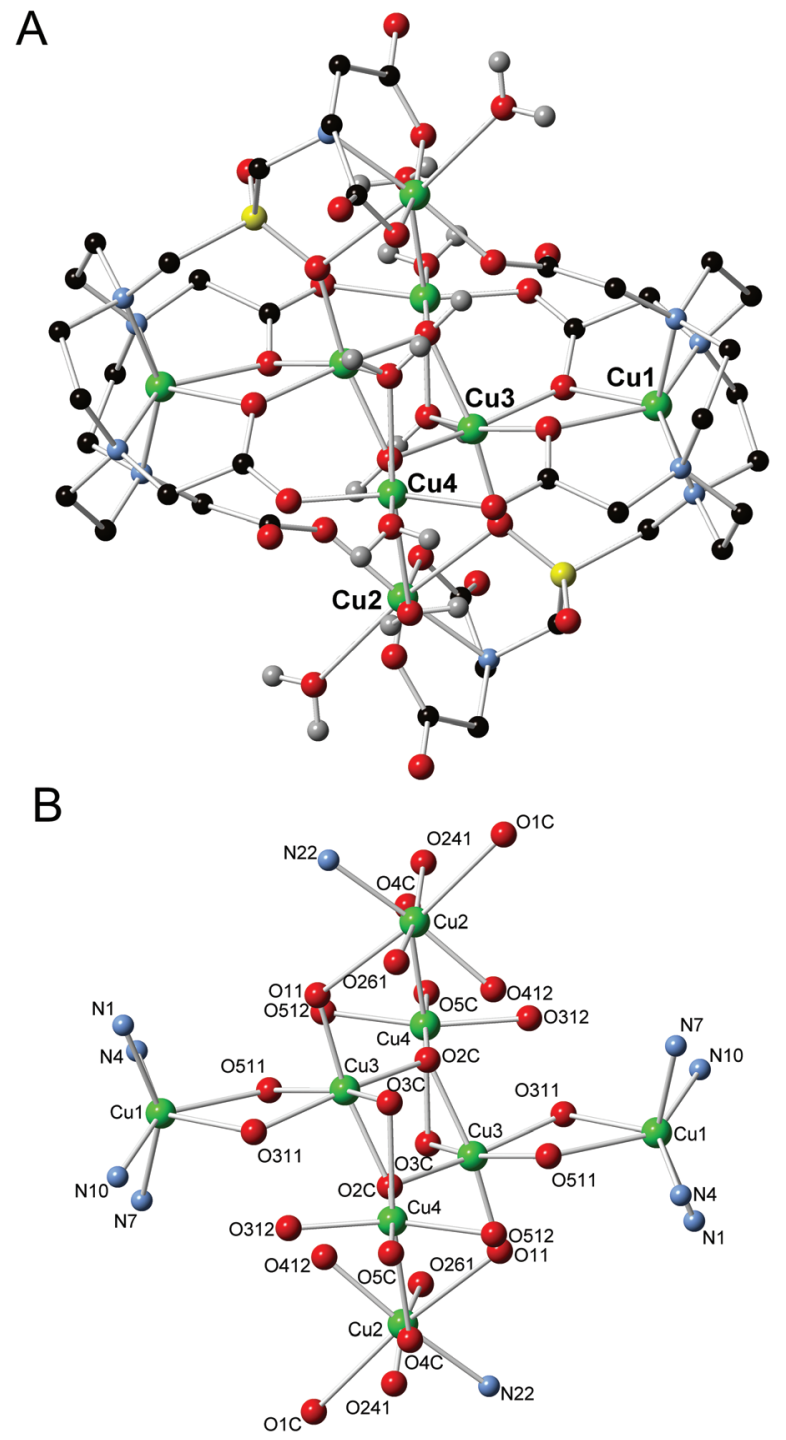

Fig. 4 Molecular structure of the dimeric $\left[\mathrm{Cu}_{8}\left(\mathrm{do} 3 \mathrm{aP} \mathrm{P}^{\text {ida }}\right)_{2}(\mathrm{OH})_{2}\left(\mathrm{H}_{2} \mathrm{O}\right)_{8}\right]^{2+}$ cation found in the crystal structure of $\left[\mathrm{Cu}_{4}\left(\mathrm{do} 3 \mathrm{aP}{ }^{\text {ida }}\right)(\mathrm{OH})\left(\mathrm{H}_{2} \mathrm{O}\right)_{4}\right] \mathrm{Cl} \cdot 7.5 \mathrm{H}_{2} \mathrm{O}(\mathrm{A}$; hydrogen atoms attached to the carbon atoms are not displayed for the clarity reasons) and the coordination environment of the dimeric $\mathrm{Cu}_{8}$ cluster ( $\mathrm{B}$; only the coppercoordinated atoms are displayed for the clarity reasons) The data were collected at $150 \mathrm{~K}$.

the equatorial plane, and the fourth equatorial position is occupied by a carboxylate of the DO3A-group from the second (symmetrically related) ligand molecule. All equatorial distances are in a narrow range of 1.9-2.0 A. The axial positions are significantly Jahn-Teller deformed and occupied by a water molecule $(2.50 \AA)$ and by a phosphinate oxygen atom $(2.70 \AA)$. The coordination spheres of the two remaining copper(II) ions are also very irregular and could be viewed as significantly axially elongated octahedrons. The two symmetrically associated $\mathrm{Cu} 3$ ions are bridged by two hydroxide anions coordinated in the distances $\sim 1.98 \AA$ (Fig. S7†). Another two coordination sites of each $\mathrm{Cu} 3$ ion are occupied by the two carboxylate oxygen atoms that are simultaneously coordinated 
to $\mathrm{Cu} 1$. One of them is placed in the equatorial position $(1.97 \AA)$ and the other one is in the axial position $(2.38 \AA)$. The fourth equatorial site is occupied by the phosphinate oxygen atom (1.93 $\AA$ ) already bound to $\mathrm{Cu} 2$ and the remaining axial position is occupied by the water molecule (2.49 A, bridging to $\mathrm{Cu} 4$ ). The $\mathrm{Cu} 4$ ion bridges the two ligand molecules (Fig. S8†) through the macrocycle acetate pendants coordinated in the equatorial plane (1.92 and $1.94 \AA$ ). Another equatorial position is occupied by the hydroxide anion bridging to two $\mathrm{Cu} 3$ ions (2.04 $\AA$ ). The remaining equatorial position $(2.01 \AA)$ and both axial positions (2.26 and $2.41 \AA$ ) are occupied by water molecules, one of them bridging to the $\mathrm{Cu} 3$ ion. The whole molecule is a complicated $\mathrm{Cu}_{8}$ cluster bridged by carboxylate, phosphinate, hydroxide and water oxygen atoms (Fig. 4). The short-

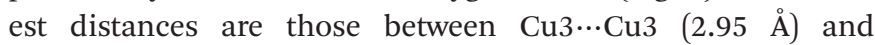
Cu3 …Cu4 (3.16 ̊) which are bridged by the tricoordinated $\mu_{3}$-hydroxido ligand.

\section{Formation kinetics of the Ce(III) complex}

The formation of the complexes of DOTA-like ligands is mostly described as a two-step process. ${ }^{8-17}$ An out-of-cage complex (indicated in formulas below with superscript "oc") is swiftly formed in the first step. In the complex, donor atoms of the pendant arms are coordinated and two macrocyclic amines are protonated and the protons block the macrocyclic cavity. In the next (rate-determining) step, nitrogen atoms of the macrocycle are deprotonated and the metal ion is simultaneously transferred into the macrocyclic cavity forming the in-cage complex (indicated in formulas below with superscript "ic") where, in the case of lanthanide(III) ions, all donor atoms of the ligands are coordinated. Recently, we have shown that different types of the out-of-cage complexes are formed if ligand or metal ion excesses are used in the reaction of lanthanide(III) ions and $\mathrm{H}_{4}$ dota. ${ }^{14}$ With metal ion excess, the out-ofcage complex has the structure discussed above where oxygen atoms of four acetate pendant arms are bound together with some water molecules. However with the ligand excess, two ligand molecules are coordinated through their pendant arms to the metal ion in the out-of-cage complex. The title ligand, $\mathrm{H}_{6}$ do3aP ${ }^{\mathrm{ida}}$, was designed to stabilize the out-of-cage complex through the coordination of the IDA moiety. Therefore, the local concentration of the metal ion close to the macrocyclic cavity would be increased and the overall complexation reaction should be possibly faster. On the other hand, too strong binding in the out-of-cage mode would decrease the complex formation rate. To distinguish between these limits, a set of complex formation experiments was performed.

The formation of the $\left[\mathrm{Ce}\left(\mathrm{do} 3 \mathrm{aP}^{\mathrm{ida}}\right)\right]^{3-}$ complex was studied by UV-Vis spectroscopy. Spectra of the in-cage complex and out-of-cage complexes are shown in Fig. S9 and S10. $\dagger$ The incage complex shows similar spectra under all applied experimental conditions. The spectra are similar to those reported for the $[\mathrm{Ce}(\text { dota })]^{-}$complex. ${ }^{13}$ The change in the maximum could be ascribed to the coordination of the phosphinate group in the title ligand. In contrast, the spectra of out-of-cage complexes are strongly dependent on the applied conditions.
The spectra obtained under the ligand excess remain unchanged along the whole studied $\mathrm{pH}$ range and they are similar to those reported for the Ce(III) $-\mathrm{H}_{4}$ dota system. ${ }^{13}$ The spectra obtained under the ligand excess are $\mathrm{pH}$ dependent and they indicate the formation of various out-of-cage species (see also lower).

The out-of-cage complexes are formed immediately (during the $15 \mathrm{~s}$ dead time). The results of potentiometry (see above) show that the IDA group is a strongly complexing group and the out-of-cage complexes are formed quantitatively even in the equimolar mixture along the whole studied $\mathrm{pH}$ range. Thus, the changes in the UV-Vis spectra describe the rearrangement of the out-of-cage species into the in-cage product. Such a process is the first order reaction and, so, the dependence of the absorbance at $314 \mathrm{~nm}\left(\lambda_{\max }\right.$ of the in-cage product) on time was fitted with the general exponential function (eqn (1)). The changes of the spectra in the course of the reaction and the corresponding fits of the data are shown in Fig. S11. $\dagger$

As the labelling with a metal radioisotope is commonly done with the ligand excess, kinetic experiments were performed under both the metal and the ligand excesses at $\mathrm{pH}$ 5.9, 6.5, 7.0 and 8.0. The obtained rate constants $k_{\text {obs }}$ were plotted against the metal-to-ligand or ligand-to-metal ratio (Fig. 5). Under the metal ion as well as the ligand excess, the curves show a saturation shape. The different mutual shape of the curves is a result of the presence of the different reaction intermediates. As mentioned above, the IDA group is a strongly complexing group and, so, the $[\mathrm{ML}]^{\text {oc }}$ species is quantitatively formed in the equimolar mixture in the studied $\mathrm{pH}$ range. So, the saturation shape of the curve under the metal ion excess indicates the formation of the $\left[\mathrm{M}_{2} \mathrm{~L}\right]^{\mathrm{oc}}$ complex. Under the ligand excess, the reaction rate is progressively decreased to a limiting value. It might be rationalized by the formation of the $\left[\mathrm{ML}_{2}\right]^{\mathrm{oc}}$ intermediate with a decreased reaction rate of the sub-

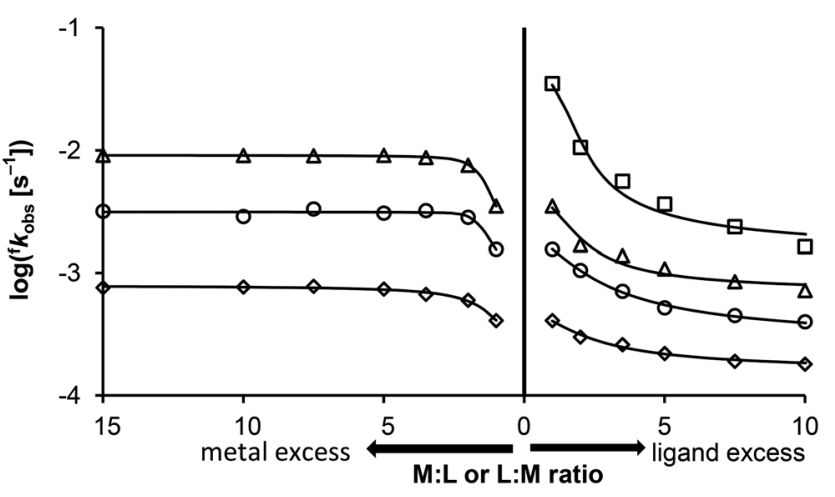

Fig. 5 Complex formation in the $\mathrm{Ce}(\mathrm{III})-\mathrm{H}_{6}$ do3aPida system performed at $25^{\circ} \mathrm{C}$ under the $\mathrm{Ce}(\mathrm{III})$ ion excess (left part, $\mathrm{C}_{\mathrm{L}}=5 \times 10^{-4} \mathrm{M}$ ) and the ligand excess (right part, $c_{\mathrm{Ce}}=5 \times 10^{-4} \mathrm{M}$ ) at $\mathrm{pH}=5.9$ (diamonds), 6.5 (circles), 7.0 (triangles) and 8.0 (squares). The highest $\mathrm{pH}$ value was not used in the experiments employing the metal excess due to the precipitation of $\mathrm{Ce}$ (III) hydroxide. The curves represent the best fit according to eqn (2)-(5) 
sequent in-cage complexation. The presence of multiple reaction intermediates is also evidenced by the UV-Vis spectra of the $\mathrm{Ce}(\mathrm{III})-\mathrm{H}_{6} \mathrm{do} 3 \mathrm{aP}^{\mathrm{ida}}$ system obtained immediately after mixing at pH 4 and 8 (Fig. 6). Keeping constant Ce(III) concentration at $\mathrm{pH} 4$, the first absorbance maximum is reached at $300 \mathrm{~nm}$ at the 2:1 metal-to-ligand ratio (Fig. 6B). With more ligand added, the absorbance further increases with gradual shifting of the maximum to $314 \mathrm{~nm}$ until the $1: 1$ metal-toligand ratio is reached, where the out-of-cage $[\mathrm{ML}]^{\mathrm{oc}}$ complex is fully formed. It indicates the formation of two different intermediates with $[\mathrm{ML}]^{\mathrm{oc}}$ and $\left[\mathrm{M}_{2} \mathrm{~L}\right]^{\mathrm{oc}}$ stoichiometry. At $\mathrm{pH}$, the spectra are changing even more dramatically. The intensity of the absorption band at $314 \mathrm{~nm}$ gradually increases and reaches maximum at the $\sim 1: 1$ metal-to-ligand ratio (Fig. 6C and $\mathrm{E})$ that corresponds to the $[\mathrm{ML}]^{\mathrm{oc}}$ intermediate and the spectra are similar to those observed at $\mathrm{pH}$ 4. At a higher ligand concentration, the absorbance at $314 \mathrm{~nm}$ decreases and a new band at $291 \mathrm{~nm}$ is observed (Fig. 6C and E). These changes in the spectra could be ascribed to the formation of the $\left[\mathrm{ML}_{2}\right]^{\mathrm{oc}}$ intermediate. Based on these observations, the overall system can be described as shown in Scheme 1.

Due to the high complexing ability of the IDA group, a mixed coordination by both the IDA group and macrocycle pendant arms is expected for the $[\mathrm{ML}]^{\text {oc }}$ complex. In the
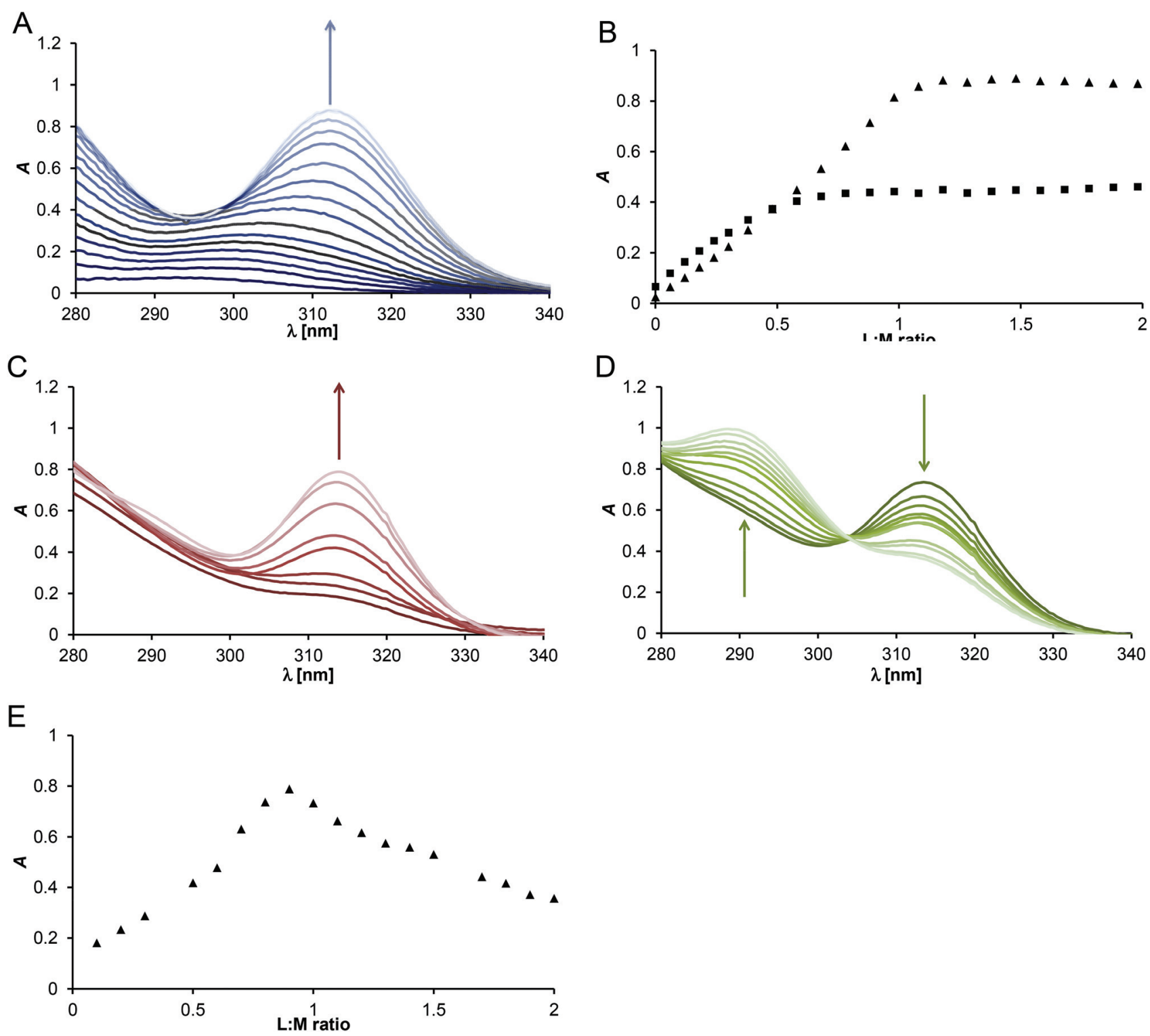

Fig. 6 UV-Vis spectra of the Ce(III)- $\mathrm{H}_{6}$ do3aP ida out-of cage complexes at $\mathrm{pH} 4\left(\mathrm{~A}, \mathrm{c}_{\mathrm{M}}=2.5 \times 10^{-3} \mathrm{M}, \mathrm{C}_{\mathrm{L}}=0-5 \times 10^{-3} \mathrm{M}\right)$ and the corresponding changes of the absorbance at $300 \mathrm{~nm}$ (squares) and $314 \mathrm{~nm}$ (triangles) with increasing metal-to-ligand ratio (B). UV-Vis spectra of the Ce(III)$\mathrm{H}_{6}$ do3aPida out-of cage complexes at $\mathrm{pH} 8$ at low ligand concentrations $\left(C, C_{M}=2.5 \times 10^{-3} \mathrm{M}, \mathrm{C}_{\mathrm{L}}=0-2.5 \times 10^{-3} \mathrm{M}\right)$ and high ligand concentration $\left(\mathrm{D}, c_{\mathrm{M}}=2.5 \times 10^{-3} \mathrm{M}, c_{\mathrm{L}}=2.5-5 \times 10^{-3} \mathrm{M}\right.$ ) and the corresponding changes of the absorbance at $314 \mathrm{~nm}$ with increasing metal-to-ligand ratio ( $\mathrm{E}$ ). The arrows indicate the increasing ligand concentration. 


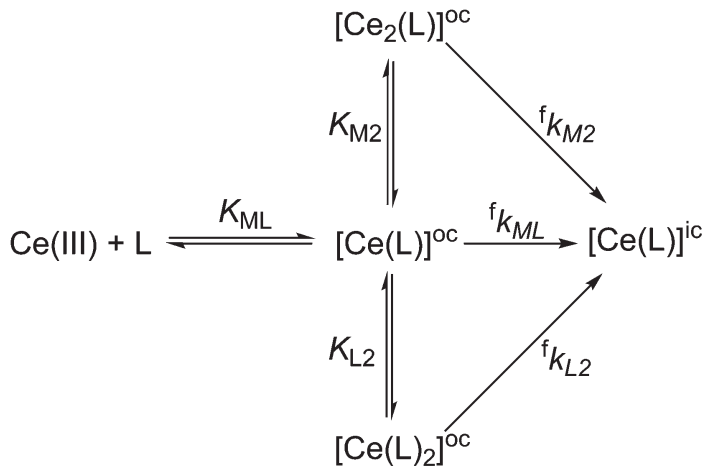

Scheme 1 Mechanism of complexation in the $\mathrm{Ce}(\mathrm{III})-\mathrm{H}_{6}$ do3aPida system.

$\left[\mathrm{M}_{2} \mathrm{~L}\right]^{\mathrm{oc}}$ complex, each coordination unit - the IDA group and macrocycle acetate arms - binds independently one metal ion. In contrast, in the $\left[\mathrm{ML}_{2}\right]^{\text {oc }}$ species, the metal ion is probably coordinated by two IDA groups originating from two different ligand molecules.

According to the mechanism suggested in Scheme 1, the rate of the whole complexation reaction to form the in-cage complex can be expressed as a sum of contributions given by transformation of all expected out-of-cage intermediates (eqn (2)).

$$
\begin{aligned}
& \frac{\mathrm{d}[\mathrm{ML}]^{\mathrm{ic}}}{\mathrm{d} t}={ }^{\mathrm{f}} k_{2} \cdot[\mathrm{L}]_{\text {tot }} \cdot[\mathrm{M}]_{\text {tot }}={ }^{\mathrm{f}} \\
& k_{\mathrm{ML}} \cdot[\mathrm{ML}]^{\mathrm{oc}}+{ }^{\mathrm{f}} k_{\mathrm{L} 2} \cdot\left[\mathrm{ML}_{2}\right]{ }^{\mathrm{oc}} \\
&+{ }^{\mathrm{f}} k_{\mathrm{M} 2} \cdot\left[\mathrm{M}_{2} \mathrm{~L}\right]^{\mathrm{oc}}
\end{aligned}
$$

where ${ }^{\mathrm{f}} k_{2}$ is a second-order rate constant of the bimolecular reaction and can be calculated from the observed pseudo-firstorder rate constant ${ }^{\mathrm{f}} k_{\text {obs }}$ by ${ }^{\mathrm{f}} k_{2}={ }^{\mathrm{f}} k_{\text {obs }} /[\mathrm{M}]_{\text {tot }}$ or ${ }^{\mathrm{f}} k_{2}={ }^{\mathrm{f}} k_{\text {obs }} /[\mathrm{L}]_{\text {tot }}$ for the metal excess and the ligand excess, respectively. Eqn (2) must be combined with metal and ligand mass balance equations and with the formula for the stability constants of the reaction intermediates (eqn (3)-(5))

$$
\begin{gathered}
{[\mathrm{ML}]^{\text {oc }}=K_{\mathrm{ML}} \cdot[\mathrm{M}] \cdot[\mathrm{L}]} \\
{\left[\mathrm{ML}_{2}\right]^{\mathrm{oc}}=K_{\mathrm{L} 2} \cdot[\mathrm{ML}] \cdot[\mathrm{L}]} \\
{\left[\mathrm{M}_{2} \mathrm{~L}\right]^{\mathrm{oc}}=K_{\mathrm{M} 2} \cdot[\mathrm{ML}] \cdot[\mathrm{M}]}
\end{gathered}
$$

where $K_{\mathrm{ML}}, K_{\mathrm{L} 2}$ and $K_{\mathrm{M} 2}$ are the conditional stability constants of the out-of-cage intermediates (see Scheme 1), [L] is the concentration of the free ligand and $[\mathrm{M}]$ is the concentration of the free metal ion. The constant $K_{\mathrm{ML}}$ is excessively high and cannot be rigorously determined from the acquired data. So, the value had to be fixed and the same results were obtained for all values $\log K_{\mathrm{ML}}>6$. Finally, the data were treated with the set of eqn (2)-(5) and using fixed $\log K_{\mathrm{ML}}=8$ in order to fulfil the minimization condition for the overall fit.

The results are shown in Fig. 5 and summarized in Table 4. The conditional stability constant $K_{\mathrm{L} 2}$ describing the coordination of the second ligand molecule is $\mathrm{pH}$ dependent as the imino-diacetate group is (partially) protonated in the studied $\mathrm{pH}$ range. Its values are comparable to the stability constant describing the consecutive coordination of the second ligand to form the $\left[\mathrm{Eu}(\mathrm{ida})_{2}\right]^{-}$complex (Table $\mathrm{S} 5 \dagger$ ). From a relatively sharp break in Fig. 5 at the L:M 1:2 ratio, one can conclude that the conditional stability constant $K_{\mathrm{M} 2}$ describing the coordination of the second metal ion is high. This suggestion is supported also by a break in absorbance at $300 \mathrm{~nm}$ (Fig. 6B). Calculations confirmed that this assumption and the values of the conditional stability constant $K_{\mathrm{M} 2}$ are about one order of magnitude higher than those of $K_{\mathrm{L} 2}$. However, the values of $K_{\mathrm{M} 2}$ were determined with a large error due to a too sharp break shown in Fig. 5 mentioned above.

To get detailed information about the $\mathrm{pH}$ dependence of the complexation process, the formation reaction was studied under pseudo-first order conditions using 10-fold ligand or metal ion excess at various $\mathrm{pH}$ values. The excess was chosen to reach the quantitative formation of the $\left[\mathrm{ML}_{2}\right]^{\mathrm{oc}}$ or $\left[\mathrm{M}_{2} \mathrm{~L}\right]^{\mathrm{oc}}$ complexes, respectively. The results are depicted in Fig. 7. Both the series of experiments show a linear increase of the formation rate with a higher concentration of $\mathrm{OH}^{-}$ions. It is in agreement with the generally accepted mechanism of the formation of lanthanide(III) complexes of DOTA-like ligands ${ }^{8-17}$ where the rate-determining step is the hydroxide ion-assisted deprotonation of the ring nitrogen atoms in the out-of-cage complex coupled with the transfer of the $\operatorname{Ln}$ (III) ion into the macrocyclic cavity. Therefore, the rate constant ${ }^{\mathrm{f}} k_{\mathrm{obs}}$ could be also expressed as general eqn (6)

$$
{ }^{\mathrm{f}} k_{\mathrm{obs}}={ }^{\mathrm{OH}} k_{0}+{ }^{\mathrm{OH}} k_{1} \cdot\left[\mathrm{OH}^{-}\right]
$$

where ${ }^{\mathrm{OH}} k_{0}$ and ${ }^{\mathrm{OH}} k_{1}$ are rate constants characterizing the $\mathrm{OH}^{-}$-independent and $\mathrm{OH}^{-}$-dependent transformation of the out-of-cage intermediate into the final in-cage complex. ${ }^{10}$

Under the excess of $\mathrm{H}_{6} \mathrm{do} 3 \mathrm{aP}^{\mathrm{ida}}$, linearity is not maintained at $\mathrm{pH}<5$ (see Fig. 7, inset B). It might be ascribed to an

\begin{tabular}{|c|c|c|c|c|c|}
\hline $\mathrm{pH}$ & ${ }^{\mathrm{f}} k_{\mathrm{ML}}\left[\mathrm{M}^{-1} \mathrm{~s}^{-1}\right]$ & ${ }^{\mathrm{f}} k_{\mathrm{M} 2}\left[\mathrm{M}^{-2} \mathrm{~s}^{-1}\right]$ & ${ }^{\mathrm{f}} k_{\mathrm{L} 2}\left[\mathrm{M}^{-2} \mathrm{~s}^{-1}\right]$ & $K_{\mathrm{M} 2}$ & $K_{\mathrm{L} 2}$ \\
\hline 5.9 & $(4.1 \pm 0.2) \times 10^{-5}$ & $(7.9 \pm 0.2) \times 10^{-4}$ & $(1.5 \pm 0.2) \times 10^{-4}$ & $(3 \pm 1) \times 10^{3}$ & $(1.8 \pm 06) \times 10^{3}$ \\
\hline 6.5 & $(1.5 \pm 0.2) \times 10^{-3}$ & $(3.1 \pm 0.1) \times 10^{-3}$ & $(2.6 \pm 0.3) \times 10^{-4}$ & $(6 \pm 10) \times 10^{4}$ & $(2.2 \pm 0.2) \times 10^{3}$ \\
\hline 7.0 & $(3.5 \pm 0.1) \times 10^{-3}$ & $(9.15 \pm 0.05) \times 10^{-3}$ & $(6 \pm 3) \times 10^{-4}$ & $(2.1 \pm 0.3) \times 10^{4}$ & $(5 \pm 3) \times 10^{3}$ \\
\hline 8.0 & $(3.4 \pm 0.1) \times 10^{-2}$ & - & $(1.4 \pm 2) \times 10^{-3}$ & - & $(1.2 \pm 0.6) \times 10^{4}$ \\
\hline
\end{tabular}
additional protonation of the out-of-cage complex or to an incomplete coordination of the second ligand molecule. However, the data do not allow one to distinguish between

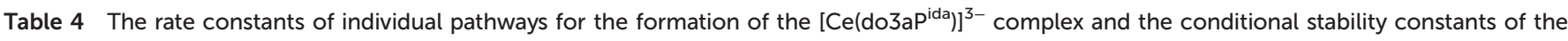
corresponding out-of-cage intermediates $\left(25^{\circ} \mathrm{C}\right)$ 

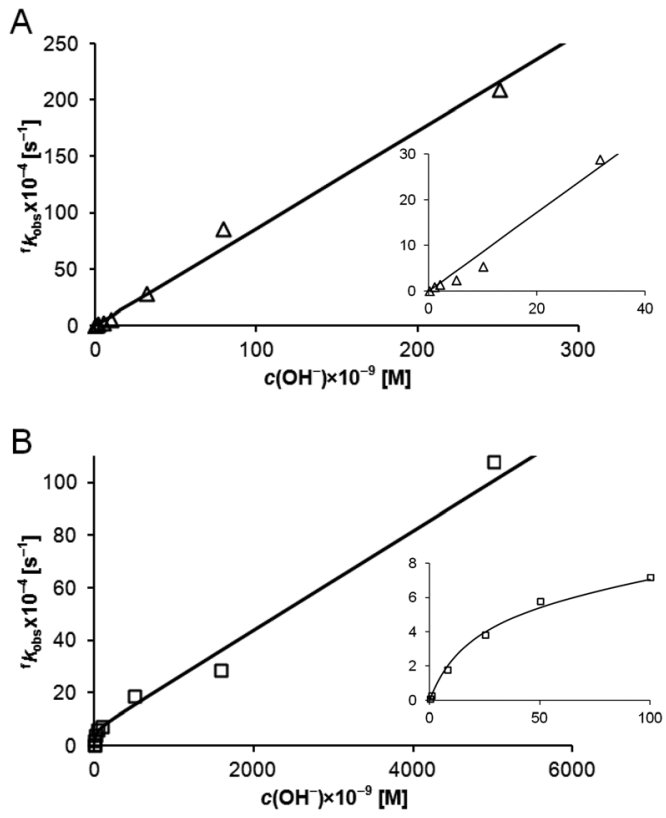

Fig. 7 The $\mathrm{pH}$ dependence of the formation rate constant values in the $\mathrm{Ce}(\mathrm{III})-\mathrm{H}_{6}$ do3aPida system using the metal excess (A, $25^{\circ} \mathrm{C}, \mathrm{C}_{\mathrm{Ce}}=5 \times$ $\left.10^{-3} \mathrm{M}, \mathrm{C}_{\mathrm{L}}=5 \times 10^{-4} \mathrm{M}\right)$ and the ligand excess $\left(\mathrm{B}, 25^{\circ} \mathrm{C}, \mathrm{C}_{\mathrm{Ce}}=5 \times 10^{-4}\right.$ $\left.\mathrm{M}, C_{\mathrm{L}}=5 \times 10^{-3} \mathrm{M}\right)$. The insets show the data obtained in the low-pH region. The solid lines correspond to the best fits obtained according to eqn (6). The line in the inset $B$ is a guide for eyes only.

these two options, so the nonlinear region was not included in the further data treatment. It also means that the constant ${ }^{\mathrm{OH}} k_{0}$ has no chemical sense (inset in Fig. 7B). Fitting the data acquired at metal ion excess using eqn (6) shows that the contribution described by the $\mathrm{OH}^{-}$-independent term is negligible. Thus, only the rate constant for the hydroxide-assisted pathway could be determined and values of the ${ }^{\mathrm{OH}} k_{1}$ are $(8.6 \pm$ $0.3) \times 10^{4} \mathrm{M}^{-1} \mathrm{~s}^{-1}$ and $(1.9 \pm 0.2) \times 10^{3} \mathrm{M}^{-1} \mathrm{~s}^{-1}$ for the metal ion and the ligand excess, respectively. The direct comparison of reaction rates shows steeper $\mathrm{pH}$ dependence under metal ion excess than that under ligand excess (Fig. 8). Thus, the $\left[\mathrm{M}_{2} \mathrm{~L}\right]^{\mathrm{oc}}$ complex shows higher reactivity than the $\left[\mathrm{ML}_{2}\right]^{\text {oc }}$ complex at $\mathrm{pH}>5$ whereas, at $\mathrm{pH}<5$, the $\left[\mathrm{ML}_{2}\right]^{\mathrm{oc}}$ species

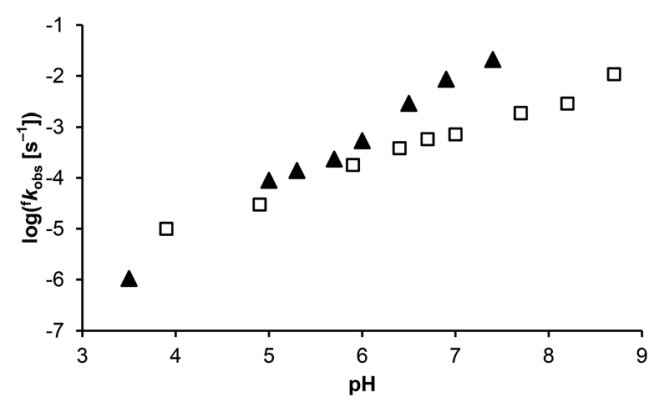

Fig. $8 \mathrm{pH}$ dependence of the rate constants for the formation of the in-cage $\left[\mathrm{Ce}\left(\mathrm{do3aP} \mathrm{P}^{\mathrm{ida}}\right)\right]^{3-}$ complex at $25^{\circ} \mathrm{C}$ under the metal excess (full triangles, $c_{\mathrm{Ce}}=5 \times 10^{-3} \mathrm{M}, \mathrm{c}_{\mathrm{L}}=5 \times 10^{-4} \mathrm{M}$ ) and the ligand excess (open squares, $c_{\mathrm{Ce}}=5 \times 10^{-4} \mathrm{M}, c_{\mathrm{L}}=5 \times 10^{-3} \mathrm{M}$ ). rearranges faster than $\left[\mathrm{M}_{2} \mathrm{~L}\right]^{\mathrm{oc}}$. The differences might be ascribed to the different basicity of the macrocycle nitrogen atoms of the $\left[\mathrm{ML}_{2}\right]^{\mathrm{oc}}$ and $\left[\mathrm{M}_{2} \mathrm{~L}\right]^{\mathrm{oc}}$ species as well as differences in their structures. The metal ion in the $\left[\mathrm{ML}_{2}\right]^{\mathrm{oc}}$ complex is dominantly coordinated by the IDA-groups and only weak interaction between the metal ion and macrocycle acetate pendants could be expected. In contrast, one metal ion in the $\left[\mathrm{M}_{2} \mathrm{~L}\right]^{\mathrm{oc}}$ species is bound to the macrocycle acetate pendants. The coordination of pendants to the positively charged metal ion leads to a decreased basicity of macrocycle nitrogen atoms. These effects result in a bigger slope of $k_{\mathrm{obs}}$ dependence on pH.

The comparison of the presented results with those for $\mathrm{H}_{4}$ dota and $\mathrm{H}_{5}$ do3aP (Table 5) shows a significant decrease of the complexation rate when the IDA group is attached to the phosphorus atom of the pendant arm in $\mathrm{H}_{6} \mathrm{do} 3 \mathrm{aP}{ }^{\mathrm{ida}}$. This is highly important information for the design of new chelators for radiomedical applications. Recently, we have shown that the pendant arms containing weakly chelating units such as hydroxomethylphosphinate, ${ }^{19}$ 2-carboxyethylphosphinate ${ }^{18}$ or methylene-bis(phosphinate ${ }^{20}$ accelerate the in-cage complexation of the metal ions. In contrast, the results presented here indicate that the presence of a more strongly complexing group in the pendant arm is not advantageous for the fast incage complexation. The complexation rate is governed by two factors - the stability of the out-of-cage intermediates and the rate of the into-cage transfer. The low stability of out-of-cage complexes leads to low abundance of these intermediate species and, consequently, to low concentration of the metal ion in the vicinity of the macrocyclic cage and, thus, slow incage complexation. The presented results show that the too

Table 5 The rate constants of formation and dissociation reactions of the discussed $\mathrm{Ce}\left(\right.$ III) complexes $\left(t=25^{\circ} \mathrm{C}\right)$

\begin{tabular}{|c|c|c|}
\hline Ligand & $\begin{array}{l}\text { Formation (half-life } \\
\text { at } \mathrm{pH} 7 \text { ) }\end{array}$ & $\begin{array}{l}\text { Dissociation }^{a} \text { (half-life } \\
\text { at pH 0) }\end{array}$ \\
\hline $\mathrm{H}_{6} \mathrm{do} 3 \mathrm{aP}^{\mathrm{ida}}$ & $\begin{array}{l}{ }^{\mathrm{OH}} k_{1}=8.6 \times 10^{4} \mathrm{M}^{-1} \mathrm{~s}^{-1} \\
t_{1 / 2}=81 \mathrm{~s} \\
\left(\mathrm{This} \mathrm{work}^{b}\right) \\
{ }^{\mathrm{OH}} k_{1}=1.9 \times 10^{3} \mathrm{M}^{-1} \mathrm{~s}^{-1} \\
t_{1 / 2}=1 \mathrm{~h} \\
\left(\text { This work }^{c}\right)\end{array}$ & $\begin{array}{l}{ }^{\mathrm{d}} k_{1}=6.9 \times 10^{-4} \mathrm{M}^{-1} \mathrm{~s}^{-1} \\
t_{1 / 2}=23 \mathrm{~min} \\
\text { (This work) }\end{array}$ \\
\hline $\mathrm{H}_{5} \mathrm{do} 3 \mathrm{aP}$ & $\begin{array}{l}{ }^{\mathrm{OH}} k_{1}=9.6 \times 10^{5} \mathrm{M}^{-1} \mathrm{~s}^{-1} \\
t_{1 / 2}=7 \mathrm{~s} \\
\left(\text { ref. } 17^{b}\right)\end{array}$ & $\begin{array}{l}{ }^{\mathrm{d}} k_{1}=1.22 \times 10^{-3} \mathrm{M}^{-1} \mathrm{~s}^{-1} \\
t_{1 / 2}=10 \mathrm{~min} \\
\text { (ref. } 17 \text { ) }\end{array}$ \\
\hline $\mathrm{H}_{4}$ dota & $\begin{array}{l}{ }^{\mathrm{OH}} k_{1}=2.7 \times 10^{6} \mathrm{M}^{-1} \mathrm{~s}^{-1} \\
t_{1 / 2}=3 \mathrm{~s} \\
\left(\text { ref. } 13^{b}\right) \\
{ }^{\mathrm{OH}} k_{1}=3.5 \times 10^{6} \mathrm{M}^{-1} \mathrm{~s}^{-1} \\
t_{1 / 2}=2 \mathrm{~s} \\
\left.\text { (ref. } 10^{d}\right)\end{array}$ & $\begin{array}{l}{ }^{\mathrm{d}} k_{1}=8 \times 10^{-4} \mathrm{M}^{-1} \mathrm{~s}^{-1} \\
{ }^{\mathrm{d}} k_{2}=2 \times 10^{-3} \mathrm{M}^{-2} \mathrm{~s}^{-1} \\
t_{1 / 2}=4 \mathrm{~min} \\
\text { (ref. } 10) \\
{ }^{\mathrm{d}} k_{1}=3.4 \times 10^{-4} \mathrm{M}^{-1} \mathrm{~s}^{-1} \\
{ }^{\mathrm{d}} k_{2}=1.6 \times 10^{-3} \mathrm{M}^{-2} \mathrm{~s}^{-1} \\
t_{1 / 2}=6 \mathrm{~min} \\
\text { (ref. } 54 \text { ) }\end{array}$ \\
\hline
\end{tabular}

${ }^{a \mathrm{~d}} k_{\mathrm{obs}}={ }^{\mathrm{d}} k_{1} \cdot\left[\mathrm{H}^{+}\right]+{ }^{\mathrm{d}} k_{2} \cdot\left[\mathrm{H}^{+}\right]^{2} \cdot{ }^{b} 10$-times metal excess. ${ }^{c} 10$-times ligand excess. ${ }^{d}$ 20-times metal excess. 
high stability of the out-of-cage complexes is also undesirable as it leads to a slow transfer of the metal ion into the macrocyclic cavity due to mutual competition of both sites for the metal ion. Only literature precedence for such slow complexation is the transfer of $\mathrm{Cu}$ (II) into the cyclam cavity when tris(2aminoethyl)amine (tren) was used as a pendant arm. ${ }^{51}$ The incage transfer rate is dependent on the nature of both out-ofcage and in-cage chelation centres and, recently, we have shown that the spacer connecting the macrocycle part with coordinating groups in the pendants is also very important. ${ }^{14}$ Moreover, the protonable groups in the pendant arms might assist the proton transfer from the macrocyclic nitrogen atoms to the surrounding environment. In the out-of-cage complex, the pendants are coordinated to the metal ion. ${ }^{52,53}$ Consequently, the formation of highly stable out-of-cage complex blocks the pendant-assisted proton transfer and the complex formation rate is decreased. Thus, the stability of the out-of-cage intermediates must be kept in a narrow range to reach the optimal complexation rate for in-cage complexation and it should be combined with an appropriate spacer. However, the kinetic data are mostly reported for "chemical" conditions, i.e. for the millimolar concentration range. The complexation of radioisotopes is mostly performed at concentrations that are several orders of magnitude lower ("radiochemical" conditions). Furthermore, various metallic impurities originating from the radioisotope production are present in the samples. As a result, the above mentioned parameters might be of different importance and the formation of the out-of-cage complexes might become highly dominant for the overall complexation rate. Thus, design of the pendant arms must be tuned for each metal ion-ligand system, and the complexation/labelling ability of such ligands should be evaluated under both "chemical" and "radiochemical" conditions.

\section{Dissociation kinetics of the Ce(III) complex}

The acid-assisted decomplexation of the $\left[\mathrm{Ce}\left(\mathrm{do} 3 \mathrm{aP}^{\mathrm{ida}}\right)\right]^{3-}$ complex was studied in 0.2-3.0 $\mathrm{M} \mathrm{HClO}_{4}$ (Fig. 9). The dependence of the observed reaction rate constant ${ }^{\mathrm{d}} k_{\mathrm{obs}}$ on the

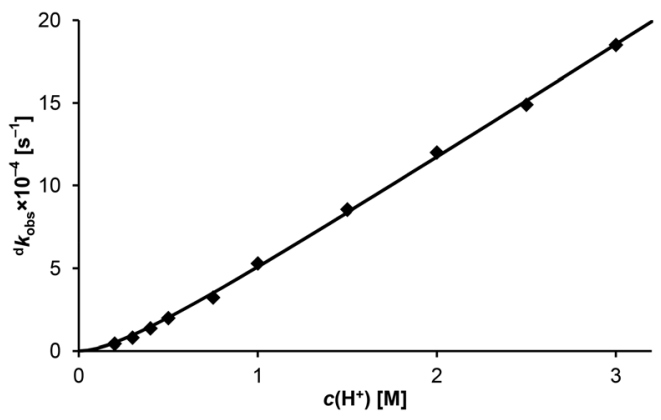

Fig. 9 Acid-assisted dissociation of the $[\mathrm{Ce}(\text { do3aPida })]^{3-}$ complex $\left(25^{\circ} \mathrm{C}, I=3 \mathrm{M}(\mathrm{Na} / \mathrm{H}) \mathrm{ClO}_{4}\right)$. The curve represents the best fit according to eqn (8). proton concentration is almost linear. However, there is a significant negative intercept on the $y$-axis. It indicates that the kinetically active species is present in two different protonation states in the studied $\mathrm{pH}$ range. There are three protonation constants of the $\mathrm{Ln}$ (III) complexes determined by potentiometry. As the studied $\mathrm{pH}$ range is below the range covered by potentiometry, $\left\{\mathrm{M}\left(\mathrm{H}_{3} \mathrm{~L}\right)\right\} \rightleftharpoons\left\{\mathrm{M}\left(\mathrm{H}_{4} \mathrm{~L}\right)\right\}^{+}$is very probably the kinetically important equilibrium that is described by the dissociation constant $K_{\mathrm{a}}$. The less protonated species, $\left\{\mathrm{M}\left(\mathrm{H}_{3} \mathrm{~L}\right)\right\}$, does not contribute to the overall dissociation. The $\left\{\mathrm{M}\left(\mathrm{H}_{4} \mathrm{~L}\right)\right\}^{+}$ species might dissociate spontaneously (rate constant ${ }^{\mathrm{d}} k_{0}$ ) or via the proton-assisted pathway (rate constant ${ }^{\mathrm{d}} k_{1}$ ). The dissociation rate is then expressed as given by eqn (7)

$$
v={ }^{\mathrm{d}} k_{\text {obs }} \cdot[\operatorname{comp}]_{\text {tot }}={ }^{\mathrm{d}} k_{0} \cdot\left[\mathrm{M}\left(\mathrm{H}_{4} \mathrm{~L}\right)\right]+{ }^{\mathrm{d}} k_{1} \cdot\left[\mathrm{M}\left(\mathrm{H}_{4} \mathrm{~L}\right)\right] \cdot\left[\mathrm{H}^{+}\right]
$$

where $[\text { comp }]_{\text {tot }}$ is the total concentration of the complex. Taking into account the protonation equilibrium suggested above, ${ }^{\mathrm{d}} k_{\mathrm{obs}}$ can be expressed by eqn (8)

$$
{ }^{\mathrm{d}} k_{\text {obs }}=\frac{{ }^{\mathrm{d}} k_{0} \times\left[\mathrm{H}^{+}\right] / K_{\mathrm{a}}+{ }^{\mathrm{d}} k_{1} \times\left[\mathrm{H}^{+}\right]^{2} / K_{\mathrm{a}}}{1+\left[\mathrm{H}^{+}\right] / K_{\mathrm{a}}}
$$

Fitting of the data according to eqn (8) gave ${ }^{\mathrm{d}} k_{1}=(6.9 \pm 0.1) \times$ $10^{-4} \mathrm{M}^{-1} \mathrm{~s}^{-1}$ and $K_{\mathrm{a}}=0.36 \pm 0.05$. The value of ${ }^{\mathrm{d}} k_{0}$ is negligible and this indicates very slow spontaneous dissociation of the $\left[\mathrm{M}\left(\mathrm{H}_{4} \mathrm{~L}\right)\right]^{+}$species. Values of the rate constant ${ }^{\mathrm{d}} k_{1}$ are comparable to those reported for the Ce(III) complexes of $\mathrm{H}_{4}$ dota and $\mathrm{H}_{5}$ do3aP (Table 5). It shows a very high kinetic inertness of the studied complex and a negligible role of the IDA-group in the dissociation process.

\section{Conclusions}

The title ligand combines the macrocyclic DOTA-like unit with the pendant IDA group and the groups are connected through a phosphinate spacer. Determined protonation and stability constants show that each group behaves as an independent chelating unit and their coordinating abilities are similar to those reported for each group as an individual molecule. The close proximity of the groups in the molecule is important for the overall complexation mechanism and significantly influences the in-cage complexation rate. In the first step, the metal ion is complexed by the IDA group in the out-of-cage mode. Several out-of-cage complexes with $2: 1,1: 1$ and $1: 2$ ligandto-metal ratios were identified. The strong complexing ability of the IDA group blocks the transfer of the metal ion into the macrocyclic cavity and, thus, the title ligand shows significantly slower in-cage complexation compared to that of the parent $\mathrm{H}_{4}$ dota. It is a significant finding as it indicates that the coordination ability of the groups in the pendant arms must be properly tuned to reach the faster chelation which is among the most important properties of ligands for the radiomedical applications. The strongly chelating pendant arm stabilizes the out-of-cage complexes too much and, thus, a suitable chelating group for the faster in-cage complexation should have only weak coordination ability. 


\section{Acknowledgements}

The support from the Grant Agency of Charles University (No. 272314) EU program COST Action 15209 (LTC17067) is acknowledged. We thank Dr I. Císařová for the collection of the X-ray diffraction data.

\section{References}

1 E. Merbach, L. Helm and É. Tóth, The Chemistry of Contrast Agents in Medical Magnetic Resonance Imaging, John Wiley \& Sons, Chichester, 2013.

2 T. J. Wadas, E. H. Wong, G. R. Weisman and C. J. Anderson, Chem. Rev., 2010, 110, 2858-2902.

3 R. E. Mewis and S. J. Archibald, Coord. Chem. Rev., 2010, 254, 1686-1712.

4 S. Cutler, H. M. Hennkens, N. Sisay, S. Huclier-Markai and S. S. Jurisson, Chem. Rev., 2013, 113, 858-883.

5 E. W. Price and C. Orvig, Chem. Soc. Rev., 2014, 43, 260-290.

6 S. Faulkner, S. J. A. Pope and B. P. Burton-Pye, Appl. Spectrosc. Rev., 2005, 40, 1-31.

7 X. Wang, H. Chang, J. Xie, B. Zhao, B. Liu, S. Xu, W. Pei, N. Ren, L. Huang and W. Huang, Coord. Chem. Rev., 2014, 273-274, 201-212.

8 J. Moreau, E. Guillon, J.-C. Pierrard, J. Rimbault, M. Port and M. Aplincourt, Chem. - Eur. J., 2004, 10, 5218-5232.

9 S. L. Wu and W. D. Horrocks, Inorg. Chem., 1995, 34, 37243732.

10 É. Tóth, E. Brücher, I. Lázár and I. Tóth, Inorg. Chem., 1994, 33, 4070-4076.

11 E. Brücher, G. Laurenczy and Z. Makra, Inorg. Chim. Acta, 1987, 139, 141-142.

12 X. Wang, T. Jin, V. Comblin, A. Lopez-Mut, E. Merciny and J. F. Desreux, Inorg. Chem., 1992, 31, 1095-1098.

13 L. Burai, I. Fábián, R. Király, E. Szilágyi and E. Brücher, J. Chem. Soc., Dalton Trans., 1998, 243-248.

14 S. Procházková, J. Hraníček, V. Kubíček and P. Hermann, Polyhedron, 2016, 111, 143-149.

15 P. Táborský, I. Svobodová, P. Lubal, Z. Hnatejko, S. Lis and P. Hermann, Polyhedron, 2007, 26, 4119-4130.

16 P. Táborský, I. Svobodová, Z. Hnatejko, P. Lubal, S. Lis, M. Försterová, P. Hermann, I. Lukeš and J. Havel, J. Fluoresc., 2005, 15, 507-512.

17 P. Táborský, P. Lubal, J. Havel, J. Kotek, J. Rudovský, P. Hermann and I. Lukeš, Collect. Czech. Chem. Commun., 2005, 70, 1909-1942.

18 J. Notni, P. Hermann, J. Havlíčková, J. Kotek, V. Kubíček, J. Plutnar, N. Loktionova, P. J. Riss, F. Rösch and I. Lukeš, Chem. - Eur. J., 2010, 16, 7174-7185.

19 J. Šimeček, M. Schulz, J. Notni, J. Plutnar, V. Kubíček, J. Havlíčková and P. Hermann, Inorg. Chem., 2012, 51, 577590.

20 T. David, V. Kubíček, O. Gutten, P. Lubal, J. Kotek, H.-J. Pietzsch, L. Rulíšek and P. Hermann, Inorg. Chem., 2015, 54, 11751-11766.
21 H.-S. Chong, S. Lim, K. E. Baidoo, D. E. Milenic, X. Ma, F. Jia, H. A. Song, M. W. Brechbiel and M. R. Lewis, Bioorg. Med. Chem. Lett., 2008, 18, 5792-5795.

22 M. Dadwal, C. S. Kang, H. A. Song, X. Sun, A. Dai, K. E. Baidoo, M. W. Brechbiel and H.-S. Chong, Bioorg. Med. Chem. Lett., 2011, 21, 7513-7515.

23 H.-S. Chong, X. Sun, Y. Chen, I. Sin, C. S. Kang, M. R. Lewis, D. Liu, V. C. Ruthengael, Y. Zhong, N. Wu and H. A. Song, Bioorg. Med. Chem., 2015, 23, 1169-1178.

24 H. A. Song, C. S. Kang, K. E. Baidoo, D. E. Milenic, Y. Chen, A. Dai, M. W. Brechbiel and H. S. Chong, Bioconjugate Chem., 2011, 22, 1128-1135.

25 S. Kang, X. Sun, F. Jia, H. A. Song, Y. Chen, M. Lewis and H.-S. Chong, Bioconjugate Chem., 2012, 23, 1775-1782.

26 I. Mamedov, N. K. Logothetis and G. Angelovski, Org. Biomol. Chem., 2011, 9, 5816-5824.

27 G. Angelovski, T. Chauvin, R. Pohmann, N. K. Logothetis and É. Tóth, Bioorg. Med. Chem., 2011, 19, 1097-1105.

28 B. McMahon, P. Mauer, C. P. McCoy, T. C. Lee and T. Gunnlaugsson, J. Am. Chem. Soc., 2009, 131, 1754217543.

29 M. Surender, S. Comby, S. Martyn, B. Cavanagh, T. C. Lee, D. F. Brougham and T. Gunnlaugsson, Chem. Commun., 2016, 52, 10858-10861.

30 A. Dadabhoy, S. Faulkner and P. G. Sammes, J. Chem. Soc., Perkin Trans. 2, 2002, 348-357.

31 V. Kubíček, J. Havlíčková, J. Kotek, G. Tircsó, P. Hermann, É. Tóth and I. Lukeš, Inorg. Chem., 2010, 49, 10960-10969.

32 C. F. Baes Jr. and R. E. Mesmer, The Hydrolysis of Cations, Wiley, New York, 1976.

33 M. Kývala and I. Lukeš, International Conference, Chemometrics '95, Pardubice, Czech Republic, 1995, p. 63, full version of "OPIUM" is available (free of charge) on http://www.natur.cuni.cz/ kyvala/opium.html.

34 (a) Z. Otwinovski and W. Minor, HKL DENZO and Scalepack Program Package, Nonius BV, Delft, 1997; (b) Z. Otwinovski and W. Minor, Processing of X-ray diffraction data collected in oscillation mode, Methods Enzymol., 1997, 276, 307-326.

35 A. Altomare, G. Cascarano, C. Giacovazzo, A. Guagliardi, M. C. Burla, G. Polidori and M. Camalli, "SIR92", J. Appl. Crystallogr., 1994, 27, 435-436.

36 G. M. Sheldrick, SHELXL-2014/7. Program for Crystal Structure Refinement from Diffraction Data, University of Göttingen, Göttingen, 2014.

37 G. Tircsó, A. Bényei, R. Király, I. Lázár, R. Pál and E. Brücher, Eur. J. Inorg. Chem., 2007, 701-713.

38 M. Pniok, V. Kubíček, J. Havlíčková, J. Kotek, A. SabatieGogová, J. Plutnar, S. Huclier-Markai and P. Hermann, Chem. - Eur. J., 2014, 20, 7944-7955.

39 M. Försterová, I. Svobodová, P. Lubal, P. Táborský, J. Kotek, P. Hermann and I. Lukeš, Dalton Trans., 2007, 535-549.

40 S. Procházková, Z. Böhmová, V. Kubíček, J. Kotek, P. Hermann and I. Lukeš, Phosphorus, Sulfur Silicon Relat. Elem., 2014, 189, 933-945.

41 I. Lukeš, J. Kotek, P. Vojtíšek and P. Hermann, Coord. Chem. Rev., 2001, 217-218, 287-312. 
42 R. Kerdjoudj, M. Pniok, C. Alliot, V. Kubíček, J. Havlíčková, F. Rösch, P. Hermann and S. Huclier-Markai, Dalton Trans., 2016, 45, 1398-1409.

43 A. E. Martell and R. M. Smith, Critical Stability Constants, Plenum Press, New York, 1974-1989, vol. 1-6; NIST Standard Reference Database 46 (Critically Selected Stability Constants of Metal Complexes), version 5.0, 1994.

44 A. Riesen, M. Zehnder and T. A. Kaden, J. Chem. Soc., Chem. Commun., 1985, 1336-1338.

45 A. Riesen, M. Zehnder and T. A. Kaden, Helv. Chim. Acta, 1986, 69, 2067-2073.

46 A. Riesen, M. Zehnder and T. A. Kaden, Helv. Chim. Acta, 1986, 69, 2074-2080.

47 J. Albalad, J. Arinez-Soriano, J. Vidal-Gancedo, V. Lioveras, J. Juanhuix, I. Imaz, N. Aliaga-Alcalde and D. Maspoch, Chem. Commun., 2016, 52, 13397-13400.
48 P. Barbaro, C. Bianchini, G. Capannesi, L. Di Luca, F. Laschi, D. Petroni, P. A. Salvadori and A. Vacca, J. Chem. Soc., Dalton Trans., 2000, 2393-2401.

49 A. Takacs, R. Napolitano, M. Purgel, A. C. Bényei, L. Zekány, E. Brücher, I. Tóth, Z. Barányai and S. Aime, Inorg. Chem., 2014, 53, 2858-2872.

50 K. Kumar, M. F. Tweedle, M. F. Malley and J. Z. Gougoutas, Inorg. Chem., 1995, 34, 6472-6480.

51 L. Siegfried, M. Honecker, A. Schlageter and T. A. Kaden, Dalton Trans., 2003, 3939-3948.

52 P. A. Stenson, A. L. Thomson and D. Parker, Dalton Trans., 2006, 3291-3293.

53 J. Šimeček, P. Hermann, J. Havlíčková, E. Herdtweck, T. G. Kapp, N. Engelbogen, H. Kessler, H.-J. Wester and J. Notni, Chem. - Eur. J., 2013, 19, 7748-7757.

54 A. Chang and Y.-L. Liu, J. Chin. Chem. Soc., 2000, 47, 10011006. 